\title{
From Buzz to Burst—Critical Remarks on the Term 'Life' and Its Ethical Implications in Synthetic Biology
}

\author{
Michael Funk (D) Johannes Steizinger • \\ Daniel Falkner • Tobias Eichinger
}

Received: 8 April 2017 / Accepted: 2 December 2019/Published online: 14 December 2019

(C) The Author(s) 2019

\begin{abstract}
In this paper, we examine the use of the term 'life' in the debates within and about synthetic biology. We review different positions within these debates, focusing on the historical background, the constructive epistemology of laboratory research and the pros and cons of metaphorical speech. We argue that 'life' is used as buzzword, as folk concept, and as theoretical concept in inhomogeneous ways. Extending beyond the review of the significant literature, we also argue that 'life' can be understood as a Burstword in two concrete senses. Firstly, terms such as life easily turn into fuzzy, foggy and buzzy clouds of nonsense, if their use is not appropriately reflected. In these cases, the semantic orientation is detonated. This is the Burstword I characteristic of the concept of 'life' that we reveal for its unclear terminological use. Secondly, and in contrast to Burstword I, we show that the concept of 'life' can be used in a methodologically controlled way. We call this kind of use Burstword II.
\end{abstract}

\footnotetext{
M. Funk $(\bowtie)$

Philosophy of Media and Technology, University of Vienna,

Vienna, Austria

e-mail: michael.funk@univie.ac.at

J. Steizinger

Faculty of Humanities, McMaster University, Hamilton, Canada

D. Falkner

SYNMIKRO LOEWE-Zentrum für Synthetische Mikrobiologie, Marburg, Germany

T. Eichinger

Institute of Biomedical Ethics and History of Medicine, University of Zurich, Zurich, Switzerland
}

Here the concept of 'life' fulfils the function of expanding an inadequately narrow disciplinary or conceptual focus in different discursive contexts. In this second sense, 'life' receives an important operational function, for instance as a transdisciplinary research principle. It turns out that the innovative function and paradigm-changing power of metaphorical speech belong here as well. Finally, we illustrate three ethically relevant examples that show how 'life' can be applied as Burstword II in the context of synthetic biology.

Keywords Life - Synthetic biology · Metaphors of life · Life as metaphor - Ethics of synthetic biology .

Buzzword · Burstword

\section{From Review to Reaction: Introduction}

As a subdiscipline of biology (the natural science of life), synthetic biology engages by definition with 'life' and its metaphors. What makes it special and new is its constructive, engineering approach. It can be said that the groundbreaking aim of synthetic biology is, as RuizMirazo and Moreno put it, 'to learn more about the living by means of re-construction or fabricating it - in contrast to the analytical-descriptive work that has, so far, been the most important way of generation knowledge in biology' ([97], p. 378). It is exactly this combination - the engineering attitude and certain life forms as its objects - that raises a lot of questions and especially engenders ethical criticism. The special ethical relevance of synthetic biology is supposed to be 
explained by the conviction that synthetic biology 'entails a confrontation with life' (ibid.). In a broader context, both conceptual and ethical questions of synthetic biology generally call for philosophical investigations into the relations in which the words 'technology' and 'life' are used ([58], pp. 117-118). In order to contribute to this challenge, we will reframe how the concept of life is used in the debates within and about synthetic biology. This paper combines a review of the current discussion with a critical reaction to these debates by suggesting another perspective that has received little attention so far: With our guiding thought, from buzz to burst, we literally advance from review to reaction. Our summary of some of the most important understandings of 'life' is thus a prerequisite for structuring the debate in a new systematic and narrative way.

The systematic contribution can be found in the attempt to combine a problematisation based on selected (but far from all) aspects of the historical background with positions in the debate about 'life' today. Another focus is metaphorical speech, such as the 'genetic code' metaphor as a metaphor of life, or 'living machines', where the term 'life' itself is part of the metaphorical construction. Our account considers two characteristic poles in the debate that emphasise both the massive critique and the positive functions of metaphorical speech for research processes. Different connotations are related to 'life' as buzzword or as folk or theoretical concept. Additionally, we introduce the idea that 'life' can be used as Burstword in two concrete ways: firstly, with a negative connotation, when it comes with the unproductive detonation of semantic orientation, due to unclear fuzzy, foggy and buzzy speech (Burstword I). The more a concept is used as a buzzword for external purposes, the more it might burst the semantic precision required for successful scientific communication - an observation that is by no means limited to the term 'life'. Secondly, it is used to broaden in methodologically controlled operations the conceptual and/or disciplinary foci wherever they are not appropriate to the intended object or problem (Burstword II). For instance, the paradigm-changing power of metaphors belongs to this side of the coin. Of course we are aware of the fact that a Burstword ( $I$ or $I I$ ) can be seen as a metaphor itselfwith all the pros and cons of metaphorical speech. Due to its epistemic function, therefore, our primary focus is on the Burstword II characteristic of 'life', which can also be seen as a metaphor for the cognitive and innovative power of metaphors. In order to make this idea more precise, we present three concrete, ethically relevant examples.

Our account is divided into five main steps ('Life Is Not Life: Aristotle's Wide Concept of Life and the Current Condensation of Modern Thinking in Synthetic Biology', 'From Buzz to Fuzz: the Dangers of the Unclear and Metaphorical Use of 'Life", 'From Buzz to Boost: Naturalisation of Life and Its Methodological Reduction in Synthetic Biology', 'From Radiation to Rehabilitation: the Positive Methodological Functions of Metaphors of Life and Life as Metaphor', 'From Buzz to False Alarm: Fallacies Regarding the Normative Effects of a Fabrication of 'Life") including two subsections each. 'Life Is Not Life: Aristotle's Wide Concept of Life and the Current Condensation of Modern Thinking in Synthetic Biology' provides an initial understanding of 'life' by recapitulating the wide Aristotelian understanding, in contrast to its current narrow use in fields like synthetic biology or astrobiology ('From Holism to Reduction and Far Beyond: Wide and Narrow Understandings of Life'). We also introduce the relationship between nature and culture as a second field of controversy, which refers to another historical root of discourses about life: the seventeenth-century mechanisation of 'life', which is highly significant for the debates about 'life' today ('From Opposition to Amalgamation: Natural and Cultural Life'). 'From Buzz to Fuzz: the Dangers of the Unclear and Metaphorical Use of "Life" turns to the characterisation of the uses of the concept of life as Burstword I and critically examines positions which we consider to be the dark side of these debates. Here 'life' is seen as a buzzword for funding acquisition or as a folk concept without any significance for scientific reasoning at all ('No Need to Argue, No Need for Definitions'). An important role is played by technomorphic metaphors with an engineering or information technological (IT) background. Whenever 'life' is addressed in metaphorical speech or becomes part of technomorphic metaphors like 'living machines' or 'genetic information', risks of ideological misuse or mystification stand in the focus of the critique ('What Is the Meta for? Risks of Technomorphic Metaphors in Uncertain Situations'). 'From Buzz to Boost: Naturalisation of Life and Its Methodological Reduction in Synthetic Biology' reconstructs the epistemology of synthetic biology in order to reveal the methodologically controlled and positive aspect of the concept of life (Burstword II). Here also, the theoretical interest in understanding 'life' as such, at least in its naturalised 
reduction, plays an important role ('Life as Theoretical Object of Synthetic Biology'). Of high significance is the constructive engineering approach, including concepts like standardisation and modularisation. In this context, we summarise some of its trademarks and the new understanding of evolution in innovation-driven 'fabrications of life' ('Engineering Under an Umbrella: Epistemology of Synthetic Biology and the Constructive Approach'). 'From Radiation to Rehabilitation: the Positive Methodological Functions of Metaphors of Life and Life as Metaphor' turns to the innovative functionality of metaphors, for instance in the context of paradigm changes. Metaphors contain a cognitive function and can serve as non-propositional truth criteria. Such a productive use of metaphors presupposes methodological control and an awareness of the status of metaphors: metaphors have to be treated as metaphors. In doing this, we aim to gain an understanding of what 'life' as Burstword II could mean ('Reveal the Revolution: Methodologically Controlled use of Metaphors as Metaphors').

In 'Reveal a Scriptorium 4.0: Linguistic and Biological Innovations of the 'Genetic Code' Metaphor', 'From Buzz to False Alarm: Fallacies Regarding the Normative Effects of a Fabrication of 'Life", 'From Misguiding Simplification to Respectful Complexity: an Argument Regarding the Ethical Focus' and 'From (Proto)Type to Hype: an Argument for and Against the Pedagogical Side Effect of 'Living Machines", we present three examples that should demonstrate in detail what we mean by using life as Burstword II. The first example remains on the level of metaphorical speech. We summarise the success story of the 'genetic code' metaphor and turn IT-traversed metaphors of life (e.g. 'genetic information') upside down: here not only is 'life' represented in IT-related terminology, but also 'information' in 'life'-related words. It is at this point where 'life' as Burstword II has power with its wide meaning-e.g. including social ways of life/behaviour - to expand the narrow, naturalised focus of IT wherever its link to the praxis/way of life of human communication has been lost ('Reveal a Scriptorium 4.0: Linguistic and Biological Innovations of the 'Genetic Code' Metaphor') Two more genuine ethical examples are presented in the sixth step. The second example involves an argument regarding how 'life' as Burstword II might broaden the ethical focus and avoid a misleading ethical fundamentalism or even ethical pseudo-problems ('From Misguiding Simplification to
Respectful Complexity: an Argument Regarding the Ethical Focus'). The third example is about the relation between 'life' and 'machine'. Here it is argued that a side effect of pedagogical self-conception can be rejected, in which the treatment of synthetic microorganisms as machines is interpreted as a prototype of the diminution of the moral respect for higher life forms such as mammals. Instead, there are good reasons to expand the understanding of 'machine' and apply it to the products of synthetic biology. In this example, in a somehow dialectical relation, the limitation of the meaning of 'life' in a methodologically controlled way literally causes a semantic undertow effect and expands the conceptual range of what a 'machine' actually is. If one is looking for another figurative and maybe experimental description: here we find an example of an indirect backdoor bursting II ('From (Proto)Type to Hype: an Argument for and Against the Pedagogical Side Effect of 'Living Machines"). These examples will receive a more detailed explanation in the related sections. They are intended to serve as suggestions for thinking out of the box, when the use of 'life' in synthetic biology is critically reflected upon. We are aware that more examples could be mentioned and developed. We see our examination as a first approach to language-critical philosophical reflections on synthetic biology and its key concepts. Such a perspective remains an ongoing challenge since it depends heavily on the interdisciplinary dynamics in the field.

\section{Life Is Not Life: Aristotle's Wide Concept of Life and the Current Condensation of Modern Thinking in Synthetic Biology}

This section provides an initial understanding of the term 'life' by introducing one of the most influential conceptualisations in the history of philosophy and sciences, developed by Aristotle. His definition will be linked to current debates in synthetic biology by focusing on two philosophical problems: (1) the narrow versus the wide understanding of the term 'life' and (2) the relationship between natural life and cultural life. Both issues find their ethical meeting point in the differentiation between matter of fact (empirical-descriptive talking about life) and 'matter of ought' (normativereflexive talking about life). Basic philosophical and ethical fields of conflict around the use of the term 'life' in synthetic biology are already inherent in Aristotle's 
concept. He was influenced by Plato, who provided the first conceptualisation of what we define as life in the Euro-American context ([60], pp. 53-54). The challenges to pre-modern ontological and metaphysical concepts of life referred, however, to Aristotle, whose ideas influenced materialistic and idealistic approaches as well as ideas of self-organisation, teleology and understanding the soul as power that establishes structure ([117], p. 475). Aristotle is one of the most important reference points of philosophical debates about life ([109], p. 99).

From Holism to Reduction and Far Beyond: Wide and Narrow Understandings of Life

What we call 'life' nowadays has been emphasised by Aristotle - and other ancient Greek philosophers - in terms of bios, zôe and psyche ([60], pp. 52-53; [109], p. 98). The term bios is associated with not only conduct and way of life but also time and duration of lifealways related to a certain species. Thereby, lifelong duties and political functions are significant for human bios ([6, 95], pp. 254-297, Pol VII 1, 1323a-VII, 17, $1337 a$ ), whereas zôe describes primary qualities of plants and animals. In contrast to artificial bodies, lived bodies are interpreted as a subcategory of natural bodies, which are characterised by innate causes for processes of movement, nutrition, growth and decay [4]. Following Aristotle, the reason and principle of lived bodies is termed psyche and thus situated inside the organic corpus ([31], p. 505). Combining a causal and formal definition, psychê is explained as secondary substance (ousia): as an essential form (eidos, morphê), which causes the realisation and fruition (energeia) of a concrete lived body, and as an innate skill of organic perfection (entelecheia). The principle of lived bodies thereby follows an incorporated aim (telos). Psychê summarises several parts of the soul (vegetative, sensitive and rational). Some parts are separated from the body, such as thinking, while others find their place of authority (archê) within concrete organs (ibid. pp. 510 512; [7], pp. 66-87, De Anima II 1, 412a-II 3, 415a). In contrast to Plato's metaphysical definition, Aristotle introduces a philosophy of nature and a biological understanding of life, including an ethical dimension of ways of life ([117], p. 475). What life actually means depends heavily on the sociocultural selfconceptualisation of humanity. Therefore, a reductionist biological treatment of 'life' always remains incomplete in comparison to the wider notion of life ([109], p. 97).

Bios, in the sense of the human political and moral way of life, belongs to a somehow holistic understanding of life - also including cultural life. This wide definition of life, as it has prominently been introduced by Aristotle and further developed by philosophers until today, stands in contrast to the more (for methodological reasons) reductionist treatment of 'life' within today's biological research - including synthetic biology. Here the term 'organism' has been replaced by 'living systems' that can be defined with respect to their evolutionary origin, the cell as basic element, as well as processes of metabolism, self-reproduction, and mutagenicity. Additional aspects depend on the concrete living system and in the case of humans also include normative characteristics ([117], p. 474). 'Life' as it is used in biology is one of the most complex terms within the field. All diverse kinds of biological knowing from several disciplinary contexts find their meeting point within this concept ([109], p. 97). Therefore, it includes more than just an enumeration of the characteristic features of recent forms of life. It is supposed to be understood with respect to the geological and phylogenetic perspective from a general natural-scientific point of view ([79], pp. 33-34).

With a growing interest in artificial life and astrobiology, the controversy over (narrow) definitions of life that are not limited to organic materiality or a terrestrial habitat has also heightened [36]. Due to the growing number of related disciplines, especially in current astrobiology, the complexity of the term 'life' has increased. It has been objected that an astrobiological definition of life on the basis of properties is not useful. Instead, different functions-including a transdisciplinary and diagnostic purpose - can be attributed to the concept of life [74]. The crucial point here seems to be that an astrobiological definition of life needs to be flexible enough to capture totally unexpected new forms of life ([79], pp. 34-36). Artificial life describes the computer-oriented modelling of processes of life ([117], p. 474), including the creation of robots ([27], pp. 132-154). In contrast to this, in synthetic biology, the characteristic aim is to design living systems that cannot be found in nature- by using organic materials ([117], p. 474; [27], pp. 155-164).

From a current point of view, the manifold definition of Aristotle illustrates the ancient roots of the umbrella status of the term 'life' in twenty-first century 
philosophy and indicates the need for non-reductionist ethical reflections about successful lifestyles in human societies. Today, the philosophy of human life aims to complement the biological understanding of life through specific human categories like communicative life(styles) and emotional life - a non-empirical approach to human forms of 'good' and 'reasonable' life ([117], pp. 475-476; [109], pp. 97-98). Since Aristotle's works have been received, the word 'life' is seen as homonymous and useful for integrative purposes as well. It serves as an umbrella concept and cannot be reduced to a scientific meaning only ([47], p. 267; [50], p. 255; [61]; [62], p. 4; [107], p. 278; [111], pp. 83-85). Life in the wide sense is more than a lived organism or organic system in a certain environment. What does this mean for the many ways in which the word 'life' is used by natural scientists, engineers, philosophers or the public? What are ethical challenges of a peculiar narrow understanding of life in synthetic biology?

In this paper, we want to argue that the difference between a wide and holistic understanding of life on the one side and a narrow and reductionist one on the other is not only a matter of definition. It also involves methodological aspects that (could and should) influence current research in synthetic biology - especially when it comes to its social implications. We therefore differentiate between two meanings of life as Burstword ( $I$ and $I I)$. As we will see in 'From Buzz to Fuzz: the Dangers of the Unclear and Metaphorical Use of "Life", the term 'life' today is used as buzzword, fuzzy or folk concept and metaphor. It might obscure, blur or ideologically misuse the linguistic order of precise scientific terminology in negative ways. Burstword I in this critical sense means that life can be used in ways that blow up communication and useful linguistic expressions. There is a concrete risk-and even the expected or unexpected danger - that 'life' can mean everything and nothing at the same time. On the other hand, it also bears a methodical function which we want to label Burstword II: The wide understanding of life - literally - can help to detonate narrowness in current research, where a disciplinary and/or conceptual tunnel view is not appropriate to the envisaged object or problem. In this second, methodological sense, 'life' as Burstword II is closely linked to transdisciplinarity as a general research principle-as it has been defined by Mittelstraß [87] and has been discussed in general
[66] as well as in the specific context of synthetic biology [61, 62, 106].

From Opposition to Amalgamation: Natural and Cultural Life

Aristotle's complex understanding of life has led to divisive discussions up to the present day, including the explicit contention with his works from a current point of view ([36]; [38]; [64], pp. 8-32). Besides the controversies over the wide and narrow understandings of life, there are debates about whether life and technology can be understood as opposites or not. The notion of 'fabrication of life' is itself an example of this ambivalence, because it raises not only fundamental doubts about whether life could be the object of fabrication but also the ontological question of whether the entities of synthetic biology are living beings or artefacts. This often-used opposition refers to Aristotle and adopts his distinction between phýsis and téchne in a modern sense: Living beings are defined as natural objects, which have the source of their growth and movement in themselves. In contrast, artefacts are seen as artificial objects, which are fabricated by human beings and exist only in relation to their use. They belong to culture ([13], p. 285, pp. 290-92). Do biological systems that are produced by human technology belong to nature or to culture? Some authors in the debate about the ontological status of the objects of synthetic biology claim that they have to be seen as a mixture of 'natural' and 'cultural' properties (ibid.; [28, 75]).

If this is right, synthetic biology shows us how problematic supposedly obvious dichotomies like nature and technique or nature and culture actually are. If the mixed character of synthetic biological systems is taken seriously, all definitions of life that are based on the dualisms of nature and technique or nature and culture have to be abandoned ([13], p. 290). It would follow that synthetic biology does not take a reductionist approach because culture would already be present in all natural descriptions of life. On the contrary, the concept of life belongs to a realm beyond the dualism of nature and culture. Especially due to current developments in synthetic biology, the strict distinction between life and technology has become questionable ([58], p. 113). Generally, moreover, in the history of philosophy as well as in the present day, life can also be seen as a concept that potentially bridges this distinction ([111], pp. 83-85). Related to the insight that life cannot be 
defined biologically only, it is not surprising that this argument leads to hermeneutical [13, 19] or even vitalistic [28] interpretations of synthetic biology, which are based on hermeneutical or vitalistic theories of life. Also-as we have summarised in the previous subsection - from a holistic point of view, the term 'life' involves aspects like (political) conduct in human societies or philosophical questions about the meaning of human existence, which go far beyond biological investigations.

A third historical development is of high significance for current debates as well. Behind the notion of 'fabrication of life'-again in a somehow narrow understanding of the term - stands the condensation of a long tradition of modern scientific thinking. Many studies mention the prehistory of the epistemological imperative of synthetic biology. It goes back at least to the seventeenth century, when - after 300 years of progress in the production of mechanical gadgets and devices - a general scientific research strategy was established in the sciences ([97], p. 376; [44], pp. 762-773). Historically, the second main epoch in the European history of biology after Aristotle started with Descartes. Here, lived bodies are seen as technical automata without any soul ([109], pp. 98-99). This notion has prefigured the mechanistic understanding of life until today ([117], p. 475). A constructivist - engineering-like — approach is essential for modern scientific thinking and actions. Synthetic biology introduces this epistemological principle into a new realm, the realm of biology: designing life as if it were a man-made machine. If this definition is granted, the groundbreaking aim of synthetic biology 'is to learn more about the living by means of reconstruction or fabricating it - in contrast to the analyticaldescriptive work that has, so far, been the most important way of generating knowledge in biology' ([97], p. 377; see also [1], pp. 9-10; [25], p. 42; [92], pp. 19-20; [107], pp. 284-285; [111], pp. 76-78).

In the debate on synthetic biology, it is exactly this combination - the engineering attitude with life forms as its objects - which mostly represents both the potentials and problems of this way of gaining and applying scientifically relevant knowledge. Two of the main theoretical problems of this combination are already prefigured in Aristotle's influential work: the one regarding a wide and narrow meaning of life, and the other, related question about amalgamations and borderlines between nature and culture. The latter also includes genuine modern historical leftovers, mainly influenced by Descartes: a condensation of seventeenth century thinking and the new controversy over 'fabricating life' or 'living machines', which leads to genuine ethical challenges ('Reveal a Scriptorium 4.0: Linguistic and Biological Innovations of the 'Genetic Code' Metaphor', 'From Buzz to False Alarm: Fallacies Regarding the Normative Effects of a Fabrication of 'Life", 'From Misguiding Simplification to Respectful Complexity: an Argument Regarding the Ethical Focus' and 'From (Proto)Type to Hype: an Argument for and Against the Pedagogical Side Effect of 'Living Machines"). Phrases like these cause conceptual challenges, since their usage in current debates remains unclear. In the subsequent third section, we turn to the dark side of the story and focus on current debates in more detail in order to emphasise the fuzzy, foggy and buzzy usage of 'life'-which we want to call Burstword I.

\section{From Buzz to Fuzz: the Dangers of the Unclear and Metaphorical Use of 'Life'}

There is also a general discussion about the status of the concept of life, adding other aspects to the already discussed issues of culture and nature, wide and narrow definitions, mechanistic and holistic worldviews. Some authors question whether 'life' is a scientific term at all. Others critically reflect on its role as buzzword in a scientific area dominated by research funding and the permanent struggle for attention and highlight the problematic aspects of its metaphorical use. In this section, we focus on the risks of this use of the concept of life and highlight the potential for ideological misuse. Broad debates once again illustrate the umbrella status of the term 'life' as well as the ongoing struggle for precise scientific application of terminology in general.

\section{No Need to Argue, No Need for Definitions}

In June 2007, an editorial article in the journal Nature claimed: 'It would be a service to more than synthetic biology if we might now be permitted to dismiss the idea that life is a precise scientific concept' ([46], p. 1032). Moreover, scientists assure us that 'the impossibility of a sharp distinction between animate and inanimate would not create difficulties for the biology in its everyday scientific practice' ([30], p. 101; [110], pp. 467-468). Thus, the possibility of a universal and precise biological definition of life is either not important, 
or simply impractical ([117], p. 474; [109], pp. 97-98, p. 102), or even pointless ([36]; [80], pp. 33-62). Life is regarded as a 'fuzzy concept' and the notion that biology allows a plurality of approaches to life appears to be satisfying ([116], p. 37). Some scientists, like Homberger, even claim that biologists have an intuitive knowledge of the border between inanimate matter and living beings but are not able to explain the phenomenon of life physically [67]. Similarly, the philosopher Gayon thinks that life could disappear as a scientific concept and remain only as a 'folk concept' for our everyday use. He claims:

When this point will be reached, life will be no longer a concept for the natural sciences, but just a convenient word in practice, in the world we inhabit. 'Life' will be a folk concept. Its specialists will be no longer chemists, biologists, and roboticists; life will be a subject for psychology, cognitive science and anthropology. ([55], p. 243).

But Gayon does not only deny that there can be a scientific definition of life in the strong sense. He also assumes that 'the recognition of 'life' has always been and remains primarily an intuitive process, for the scientists as for the layperson. However we should not expect, then, to be able to draw a definition from this original experience' (ibid., p. 231). Against this background, it is not surprising that some criticise the fact that the concept of life is only used as a buzzword to draw attention in a world in which the selling of a scientific result is as important as the result itself ([107], p. 276). Moreover, in its various linguistic variations, from 'fabrication of life' to 'living machines', the term 'life' is used in a metaphorical way when it comes to synthetic biology. It connotes technological progress, funding opportunities, reputation in a certain field of investigation and social and medical welfare, but it also has an explicitly negative connotation for 'playing god', loss of control, high risks and unforeseeable dangers.

The metaphorical treatment of 'life' relates (a) to a plurality of concrete technical and scientific approaches in synthetic biology (metaphor of fuzzy concepts), its disappearance as scientific term (metaphor of folk concept) or as a vague expression in certain funding contexts (metaphor of buzzword). Besides the usage of 'life' as a metaphor for something else, the other side of the coin plays an important role in current debates as well: metaphors that stand for life. For instance, the term 'living machine' not only does apply the term 'life' in a metaphorical way but also expresses something about life - not as the subject but as the object of the phrase. Here 'machine' can be seen as a metaphor for life. Another prominent example is the 'genetic code' metaphor. In this second sense, metaphors of life attract a certain interest since they immediately touch on a field of controversy that has been briefly introduced in 'Life Is Not Life: Aristotle's Wide Concept of Life and the Current Condensation of Modern Thinking in Synthetic Biology': Is, e.g. 'living machine' a metaphor for life in the narrow sense of the word? Or is it a metaphor for scientific nonsense, because a machine (= culture) can never be alive (= nature)? Or vice versa: Is it a symbol for postmodern plurality? And what is it today, after synthetic biology has emerged as a dominant field? Is it now a metaphor for the end of the ancient natureculture distinction and hence for the breakdown of traditional categories? This last question involves a potential loss of linguistic and practical orientation, which easily engenders dangers of methodical nonsense in scientific investigations or ideological misuse in public debates. In fact, negative issues are often highlighted when metaphors of life and life as metaphor are discussed.

What Is the Meta for? Risks of Technomorphic Metaphors in Uncertain Situations

To a large extent, the metaphors in synthetic biology are borrowed from the fields of engineering, construction and architecture, electrotechnics, information theory or information technologies (IT), computer science, design and theology ([29], pp. 70-71; [2], pp. 83-95; [50], pp. 258-260; [81], pp. 19-24; [86]). The technomorphic model of life-as we have already emphasised in 'From Opposition to Amalgamation: Natural and Cultural Life'-has been established since Descartes and the seventeenth century in terms of technical apparatus and automata ([109], pp. 99-100). Additionally, due to the engineering approach, the newness and complexity of synthetic biology is explained in mechanistic and industrial analogies, and mainly in terms of technical artefacts and industrial products, such as 'living machines', 'designing life' and 'life as a toolbox' [39, $43,85,93]$. It is currently adverted that machine and 
engineering metaphors in synthetic biology are hiding alternative evolutionary or ecological metaphors. Hence, alternative technological and social developments in relation to synthetic biology are also 'downplayed' [21]. These metaphors depictagain-how synthetic biology touches culturally and normatively charged and deeply rooted distinctions of living and not living matter (see 'Life Is Not Life: Aristotle's Wide Concept of Life and the Current Condensation of Modern Thinking in Synthetic Biology'). In this situation of uncertainness and blurred boundaries, which are characteristic for synthetic biology, the vocabulary of 'ontological chimeras' and 'hybrid practices' is meant to help in defining the epistemological and ontological status of technically produced new life forms [91]. Therefore, the use of metaphorical terms could be seen as an

attempt to find forms of speech which make communicable the characteristics of the scientific field and the targeted products, but it is also an indicator of the uncertainty which synthetic biology creates by propagating the crossing of the classical distinctions [84].

Furthermore, the mechanistic and technomorphic metaphors in synthetic biology are interpreted as expressions of an ontological constitution of a new world of objects ('Ontologisierung') and therefore as the cause of a potential change in our concept of life and of human self-understanding [23]. Finally, metaphors such as 'playing God' and 'creating life' are taken as an indicator of social discontent and moral irritation. In this view, they are seen as ciphers on the surface of societal discourses which refer to a deeper sociocultural dimension in the debate on synthetic biology including fear and 'Unbehagen' (discontent) [96] and the symptoms of a crisis of natural sciences ([27], pp. 19-23).

It is remarkable that the most metaphorical terms in synthetic biology are associated with mere negative connotations. They are, for instance, evaluated as 'inadequate and avoidable' ([29], p. 73) or even 'disturbing' ([39], p. 34). Boldt et al. argue that a careless and nonreflective use of metaphors could imply a dangerous artificialisation of nature and therefore is a 'real risk' with regard to the ethical implications ([23], p. 55; [22]).
With respect to the description of CRISPR-Cas9 technologies, Ceccarelli concludes that

conceiving of technologies as living things might be just as troubling because it takes responsibility away from the people who are using those technologies and places it in the metaphoric hands of the technologies themselves, absolving us of accountability for the acts performed. ([33], p. 11)

Müller cautions about the 'tempting suggestion of life being controllable' and emphasises the ethical and bio-political challenges of such metaphors like 'living machines' as 'forms of knowledge' that also 'imply the appropriate way to deal with those biotic entities' [91]. Though Martern et al. concede a structuring, orienting and active guiding function of metaphors, they also emphasise 'problematic [...] further associations invoked by the metaphors and their background' [84]. Overall, there seems to be agreement that there is a risk - or even a danger - in using metaphors of life in the scientific context as well as in public communication. For instance with respect to reporting practices in two large German newspapers, a sociological investigation has lately revealed that the

newsworthiness of a revolutionary technology and scientific discipline appears to determine the semantics of news coverage [...], while a responsible use of metaphors and their possible implications is simply lacking and this constrains responsible thinking as well. ([45], p. 14)

From a critical perspective on the rhetorical and ideological dimensions, metaphors in science have the ambivalence of 'mythification' if they are taken literally. The metaphor then turns from a productive model of thinking to a constraint of thinking that prevents scientific insight rather than enabling it [42]. Venter [113] claims that he created synthetic life when he 'activated' and 'booted' the synthetic genome in the bacterial cell. But, not only does he presuppose a very limited, reductionist definition of life in order to create it, many critics have denied that he created 'life' at all [35]. Due to the indefinability of the term 'life', Schummer even argues that the declaration of 'constructing life' as the goal of scientific inquiry is neither achievable nor does it serve 
to increase scientific knowledge or technical benefit. Hence, the claim of 'making life' is more for the sake of gaining attention and grants than for the purpose of formulating a scientific goal [104]. Therefore, whatever might be meant by 'creating/making/designing/constructing life' or 'writing/programming the code/ software of life' in a scientific sense, it is certainly over-ambitious and highly questionable to contend that '[s]ynthetic life will enable us to understand all life on this planet and to enable new industries to produce food, energy, water and medicine as we add 1 billion new humans to earth every 12 years' [113]. Here, metaphors of life turn out to be (mis)used as 'future-driven and techno-utopian ways of scientific practice' [91] and rhetorical vehicles of dubious promises and unrealistic visions, which contribute to a 'Hope, Hype and Fear Technology' [98] and rule the 'campaign of framing' [3] in the public debate on synthetic biology. Generally, the unreflected usage of genetic metaphors at the cutting edge between the scientific community and the public, e.g. those of 'genetic receipts' in comparison to 'cooking receipts', bears dangers of misunderstandings due to a lack of linguistic objectivity ([101], p. 65).

What we illustrate in this paper as buzz to burst finds its first critical climax at this point of the story. Foggy, ideologically misused, mythical phrases create a methodologically unsatisfying and useless semantic mud. A concrete meaning is hard to grasp and therefore critical verification or falsification remains impossible. Whereas the 'buzz' can somehow productively support investigations in synthetic biology in the context of funding acquisition (life as buzzword), incautious metaphorisation too easily leads to a risky 'burst' of the semantic field. If a strict scientific definition of life is not needed ('folk concept'), then metaphorical phrases do not really support clear and straightforward scientific communication. In a non-methodological, negative sense, life might become something we like to call Burstword I since it erodes conceptual borderlines and leads to a methodological lack of (semantic) orientation. This is, so to speak, the dark side of the story-life between buzzword, fuzzy concept, folk concept and mythical metaphor, including ideological misuse. But there is also another very important side. In the following sections, we will reveal, step by step, another positive and methodologically controllable impact of the term 'life' in synthetic biology.
From Buzz to Boost: Naturalisation of Life and its Methodological Reduction in Synthetic Biology

After having discussed some critical issues of the metaphorical use of the term 'life' as the fuzzy, foggy and buzzy Burstword I, we will now reconstruct some positive aspects that lead us to the methodological meaning of Burstword II. A crucial point is that from a languagecritical point of view the already-mentioned self-conception/self-understanding of humanity plays an important role in research. Here, the concrete ways of describing phenomena like 'living machines' involve a selfexplication of the concrete laboratory performances in relation to an intended aim or more general theoretical motivation. Whenever people talk about phenomena, a self-explication is at least indirectly present in the concrete choice of words, descriptions, or - in our casetechnomorphic metaphors linked to 'life'. Making the self-explication explicit is one important task of philosophy since language use is the primary object, and at the same time also the tool of philosophical assessment. Therefore, in the previous sections, we reconstructed the historical background with respect to Aristotle ('Life Is Not Life: Aristotle's Wide Concept of Life and the Current Condensation of Modern Thinking in Synthetic Biology') and summarised some critical remarks on metaphorical, fuzzy, foggy and buzzy speech ('From Buzz to Fuzz: the Dangers of the Unclear and Metaphorical Use of 'Life"). In the following section, we are going to briefly illustrate the theoretical motivation of synthetic biology — where the aim is to understand what life is ('Life as Theoretical Object of Synthetic Biology') - and its constructive epistemology ('Engineering Under an Umbrella: Epistemology of Synthetic Biology and the Constructive Approach'). Here the selfexplication receives a methodologically more productive function, which can be applied to the innovative function of metaphors as well ('From Radiation to Rehabilitation: the Positive Methodological Functions of Metaphors of Life and Life as Metaphor'). Up to this point, we treat the self-conception-which is linked to the operational self-explication while using languagein a genuine methodological sense. It is a precondition of communication in the field. On the other hand, the naturalisation of life- which is a trademark of successful engineering methodology under the umbrella of synthetic biology ('Engineering Under an Umbrella: Epistemology of Synthetic Biology and the Constructive Approach') - brings specific ethical challenges of a 
back projection to human life, which go beyond what we call Burstword I. The reason can be found in IT metaphors of 'genetic information', which easily lead to the fallacy that human communication (exchange of information in social situations) can be naturalised as well ('Reveal a Scriptorium 4.0: Linguistic and Biological Innovations of the 'Genetic Code' Metaphor').

\section{Life as Theoretical Object of Synthetic Biology}

It is important to mention that synthetic biology can also be seen as an exception in the debate about life. Here, the concept of life is not only used as buzzword or anything similar but is also discussed theoretically. Many scholars in the field-philosophers as well as natural scientists and engineers-assure us that they want to contribute to the basic understanding of life ([44], pp. 762-763). Due to experimental results like the 'synthetic cell' created by Venter and his colleagues [56], the debate on the question 'What is life?' has reignited. Bedau, for instance, emphasises that 'we now have an unprecedented opportunity to learn about life. Having complete control over the information in a genome provides a fantastic opportunity to probe the remaining secrets of how it works' [8]. Others, like Caplan, conclude that we have already learnt enough to end an old and for a while forgotten debate:

Venter and his colleagues have shown that the material world can be manipulated to produce what we recognize as life. In doing so they bring to an end a debate about the nature of life that has lasted thousands of years. Their achievement undermines a fundamental belief about the nature of life that is likely to prove as momentous to our view of ourselves and our place in Universe as the discoveries of Galileo, Copernicus, Darwin and Einstein. [32]

Here, again, we touch one of the conceptual fields that have been introduced in 'Life Is Not Life: Aristotle's Wide Concept of Life and the Current Condensation of Modern Thinking in Synthetic Biology'. The theoretical interest in understanding what life is remains primarily narrow. Broader meanings, as for instance social, political or moral life and its ethical reflection, remain either secondary-e.g. when interdisciplinary working groups emphasise the social consequences regarding risk management, medical innovations or biopolitics - or are totally blended out. Consequently, Venter claims that his synthetic genomics approach will provide a reductionist explanation of life ([34]; [44], p. 763). Since, as Morange puts it, 'life is on the way to being "naturalised", it thus seems "fully accessible to scientific enquiry' ([89], p. 181). In order to understand the significance of synthetic biology for that 'dramatic change' (ibid.), we will consider epistemological principles of synthetic biology in the following subsection.

Engineering Under an Umbrella: Epistemology of Synthetic Biology and the Constructive Approach

Not only life is treated as either a narrow reductionist or a wide umbrella term. 'Synthetic biology' also receives an umbrella status since the field clusters a set of different scientific and methodological disciplines that share a constructive approach to their object ([14, 24]; [49], p. 6). In this respect, synthetic biology can be seen as a new form and development of biotechnology. Both in comparison and contrast to other biotechnologies, synthetic biology systematically introduces engineering concepts and methodologies like standardisation, modularisation ('BioBricks') and hierarchical organisation into the field of biology ([20], pp. 391-392; [25], pp. 31-32; [44], p. 772; [49], p. 4; [59], pp. 189-190; [81], pp. 29-30). Moreover, as both practitioners and theoreticians of synthetic biology emphasise, synthetic biology research has a creative and technologically innovative aim: Novel products with useful functions should be designed in a rational manner ([20], p. 392; [24], p. 35-39) - it is at this point where technomorphic metaphors could also contribute to new research strategies (see 'From Radiation to Rehabilitation: the Positive Methodological Functions of Metaphors of Life and Life as Metaphor'). At best, the human-designed biological systems cannot be found in nature and cannot genetically interact with natural organisms. Therefore, the concepts of 'xeno-life' and 'recorded life' are emphasised in the orthogonal approach. The aim is

to create cells that are unable to exchange genetic information with natural organism either by integrating non-natural molecular compounds (xenolife) or by reassignment of the natural genetic code (recoded life). ([25], p. 30; see also ibid., pp. 36-47 and [49], p. 7) 
Xeno nucleic acids (XNAs), synthetic nucleic acid analogues, have been developed as the artificial pendant to DNA and are intended to serve as something like a 'genetic firewall', because XNA molecules are not supposed to be biochemically incompatible to DNA molecules of natural organisms ([25], p. 33, p. 39, pp. 43-45; $[82,100,102])$. With biochemical means, the design of synthetic cells should lead to genetically non-natural forms of life that are termed 'xeno-life'.

Briefly speaking, with synthetic biology, engineersbut also computer scientists - are entering biology and bringing along an epistemological model of biological research. Synthetic biology is not only the application of theoretical knowledge but also the 'fabrication' of biological systems should also lead to a better understanding of their composition and functioning. The phrase 'knowledge through fabrication' ([97], p. 377) summarises the methodological approach of the various forms of synthetic biology ([75], pp. 160-161) - such as the aforementioned notion of 'fabricating life'. To sum up their attitude, several scientists refer to Richard Feynman's saying: 'What I cannot create, I do not understand' ([44], p. 762; [97], p. 377; [115], p. 17; [1], p. 14, p. 24; [92], pp. 3ff.; [107], S. 279).

If life is going to be engineered or programmed as an artificial — still organic but non-natural - tool, what does this mean for concepts of evolution that so dramatically changed our understanding of natural life since the nineteenth century? Toepfer reflects on the impact of evolution on the notion of both 'life' and 'machine'. He emphasises the tension between life as a value-laden reflexive term on the one hand and 'life' as a descriptive concept within biological research in the debate on synthetic biology on the other ([111], p. 71). He rejects the full relevance of genealogical trees and phylogeny to future definitions of natural life:

After the creation of the first synthetic organism, the universal genealogical connection of living beings will be the restricted empirical criterion only for life as it can be found in nature (natural life), and not for life per se. (ibid., p. 86)

Toepfer concludes that 'with the creation of living machines synthetic biology will not necessarily strengthen our purely mechanistic view of life but rather broaden our concept of machines' (ibid., p. 82). The somehow narrow understanding of life in synthetic biology can also be illustrated by its fixation on individual objects. For technical reasons of means-end fulfilling functionality, even the status of evolution becomes questionable for the products of synthetic biology:

the sequence of organisms in time and the possibility of evolution is rather neglected, or, for reasons of safety and sustainable use, even intentionally suppressed. Life in synthetic biology is the reproducible set of functions and activities resulting from the composition of individual organisms that ideally remains the same across generations. (ibid., p. 84)

Loos comes to a similar conclusion. Attempts to understand life by recreating it can be realised by following the minimal cell approach. Here it is aimed to realise 'the smallest possible' but still functioning cellular life form, following the assumption that life relates to very concrete functions like replication and protein synthesis that are precisely located at certain genes. Therefore, capacities for evolutional development have been functionally decreased, or even eliminated, such as the connection to phylogenetic trees ([79], pp. 37-41).

The constructivist approach of synthetic biology does not only influence a reductionist, naturalised and theoretical understanding of what life means. Additionally, it adds a similarly narrow concept of evolution to the methodological and linguistic toolbox of current biology: evolution becomes a controllable parameter. Especially, in its methodological motivations, the narrow treatment of life and evolution is ethically not bad per se. Instead, concrete methodological requirements of scientific - or in the field of synthetic biology even technoscientific [53, 90, 92] - engagement call for this streamlined, although limited, understanding of life. In 'From Misguiding Simplification to Respectful Complexity: an Argument Regarding the Ethical Focus', we will show that this does not automatically lead to any disrespect of life as such (in the wide sense) and that practical complexity is increased at the same time. Concrete ethical assessment of specific applications of synthetic biology, its research practice and terminology, remains an ethical challenge - besides the pros and cons of a fundamental objection to the narrow treatment of life. Moreover, as we will show in the subsequent 'From 
Radiation to Rehabilitation: the Positive Methodological Functions of Metaphors of Life and Life as Metaphor', positive methodical functions of metaphorical speech in synthetic biology can also be revealed. What remains an ethically critical issue is the clash of 'matter of fact' and 'matter of ought' if naturalised speech is not only linked to technical functions of 'living machines' but also linked to human cultural life. Due to the massive usage of IT metaphors like 'genetic information', the naturalisation of human communication as if it were only the exchange of factual information also affects speech about 'life'. The ethical pitfall can be found in the risk that these semantic influences from the IT side are overlooked due to the primary focus on 'life' in the debate ('Reveal a Scriptorium 4.0: Linguistic and Biological Innovations of the 'Genetic Code' Metaphor').

\section{From Radiation to Rehabilitation: the Positive Methodological Functions of Metaphors of Life and Life as Metaphor}

As is seen in 'From Buzz to Fuzz: the Dangers of the Unclear and Metaphorical Use of 'Life", an evaluation of the metaphorical speech of 'life' as disturbing, risky, dangerous, inadequate and/or ideological mystification has a long tradition in the contempt and criticism of metaphors in science. In order to prepare the ethical arguments in 'From Buzz to False Alarm: Fallacies Regarding the Normative Effects of a Fabrication of "Life" and to further emphasise the epistemological aspects summarised in 'From Buzz to Boost: Naturalisation of Life and Its Methodological Reduction in Synthetic Biology', we will now focus on another side of the use of metaphors in synthetic biology: the methodological benefit in the context of cognitive and innovative functions, non-propositional truth criteria, paradigmatic changes of research approaches, theories and terminology. Metaphors play an important role for the inherent dynamics of research and development insofar as they can also be seen as driving forces in epistemic boundary crossing (Burstword II, 'Reveal the Revolution: Methodologically Controlled use of Metaphors as Metaphors'). We briefly reframe these issues with respect to the metaphor of the 'genetic code' in 'Reveal a Scriptorium 4.0: Linguistic and Biological Innovations of the 'Genetic Code' Metaphor'. Here also, the need to explicate metaphors as metaphors is accentuated - this time with a focus on a reductionist naturalisation and self-explication that is already inherently included in IT vocabulary.

Reveal the Revolution: Methodologically Controlled Use of Metaphors as Metaphors

Against the background of the ideal of a deductive logic of explanation, metaphors as well as models, the scientific counterpart of metaphors, were rejected as mere ornamental and heuristic aids rather than rational instruments of theoretical explanation [42, 65]. But with the crisis of such a rationalistic ideal, as it has been postulated and introduced by philosophers of science like Kuhn, metaphorical terms and model explanations were also reevaluated and rehabilitated [76]. Authors like Black and Hesse argued for a constitutive role and cognitive content of metaphors and models in scientific explanation and paradigm shifts $[15,65]$. According to Black, theoretical models in science, understood as 'explicit metaphors' [16], introduce a new perspective and new vocabulary to speak about things. They initiate an analogical transfer of isomorphic relations from an already known and familiar domain to a new and unknown domain of scientific investigation on a rational basis ([15], pp. 238-239).

Hesse calls this function the 'redescription of the domain of the explanandum' ([65], p. 157). In this process of redescription, metaphors and models are closely linked and serve as a constitutive base and driving force on the level of scientific paradigms and research programs: 'Scientific revolutions are, in fact, metaphoric revolutions, and theoretical explanation should be seen as metaphoric redescription of the domain of phenomena' ([5], p. 156). Therefore, metaphors are not mere ornamental and irrational epiphenomena of research but rather can be seen as an inevitable condition and rationale of scientific innovation and progress with a specific cognitive function [26, 78, 83]. Zwart discusses the imaginative function of the metaphorical analogy 'between synthetic cell diagrams and mandalas [which] not only pertain to the role of the object [...], but also to the subject pole (the researcher [...]).' ([118], p. 14). However, this fundamental epistemic function of metaphors does not imply that they are infallible and innocuous at all. Metaphorical shifts and transfer processes, although they are based on cognitive and rational analogies, are not deductive and fully controllable [42]. They serve as non-propositional criterion of 'rightness' [57], which Arbib and Hesse call a "pragmatic criterion' 
plus 'ideology" ([5], p. 159). Furthermore, due to the selective 'highlighting and hiding' function [77], they also carry the risk of mythification and misuse $[11,12$, 112] (see 'What Is the Meta for? Risks of Technomorphic Metaphors in Uncertain Situations'). At this point, the need for a methodologically controlled reflection on metaphors as metaphors in scientific inquiry as well as in public debates is evident, but it is still a controversial and challenging task ([42]; [69], pp. 106-112).

Besides critical aspects and risks, one can also figure out an innovative, creative, pragmatically useful and even revolutionary function $[41,72]$ and epistemic normativity of metaphors as conditions and driving forces of scientific inquiry, technological progress and societal discourses. Metaphors (and models) in this perspective appear as constitutive moments of paradigm shifts in the research process on all levels of theory building; practical norms of science; technological development; and the accompanying political, social and ethical discourses. In the current debate, for example, Szymanski has opened up the opportunity to replace passive machine metaphors in synthetic biology by more active descriptions of microorganisms as 'participators'. This might open up new experimental directions [108]. Generally, a metaphorological analysis of synthetic biology has to include the diachronic-historical perspective on the genealogy of a metaphor as well as the synchronic dimension of the systematic-ethical consequences - as has been emphasised, e.g. by Blumenberg [17] and Weinrich [114]. The diachronichistorical perspective often includes one or both of the two lines of conflict we introduced with respect to Aristotle in 'Life Is Not Life: Aristotle's Wide Concept of Life and the Current Condensation of Modern Thinking in Synthetic Biology'. For instance, in their recent study, Matern et al. [84] provide such a metaphorological attempt on the genesis and systematic implications of 'living machine' as a leading metaphor of synthetic biology. They locate the historical origin of this metaphor in Kant's conception of life, which contains an epistemological and ontological reflection on the line between organism and machine and marks 'a point of condensation where the shifting of boundaries, the eruption of the previous distinction becomes observable and processable'. ${ }^{1}$ According to the authors, this metaphorically generated tension which bears the gap and undissolvable 'surplus' that differentiates living organisms from artificial machines is still present in the use of the metaphor 'living machine' in synthetic biology. Furthermore, it also carries some ethical challenges:

For ethical research, the dealing with the ambiguity of this metaphor allows on the one hand to try to get to the bottom of the determination of boundaries between a mechanization of life and a vitalization of the machine, on the other hand it allows to examine the relation of such an ethical determination of boundaries to the self-concept of the researchers in synthetic biology [...]. (ibid., p. 57)

Besides the innovative function and epistemic normativity, two more functions can be differentiated as well. A reflexive critical function of metaphors lies in its potential to open up new perspectives by introducing alternative description languages that can correct established theoretical concepts. Thirdly, an argumentative function relates to 'metaphors as truth-apt statements' in the praxis of social reasoning ([50], p. 258, p. 263). Function two and three can be seen as concrete facets of the overarching innovative function. Metaphors also have important didactic functions when it comes to the popularisation of sophisticated scientific concepts. For instance, the metaphor of a 'genetic program' or 'receipt' is useful for this purpose - even if there still remains a lot of inaccuracy in the details ([101], pp. 60-61; see also [37] and [40], pp. 581582). Another example is the interface between science and the public or developers and users in manuals and technical documentation [54].

Reveal a Scriptorium 4.0: Linguistic and Biological Innovations of the 'Genetic Code' Metaphor

Another influential metaphor in synthetic biology is the 'genetic code', respectively 'DNA as the software of life' and the accompanied semantic fields of 'reading', 'writing' and 'information'. If one is willing to relate it to the nowadays often-used 'industry $4.0^{\prime}$ ' phrase, it might also be possible to talk about a biological 'scriptorium 4.0'. However, from a metaphorological perspective, the story, from the discovery of DNA in the middle of the twentieth century to the synthesis of a whole bacterial genome by the Venter team, is also the

\footnotetext{
${ }^{1}$ Here the distinction between physis, nature, techné and technology made since the ancient philosophy is meant.
} 
success story of a metaphor. It is the story from reading the genetic code to writing DNA in digital code of bits and bytes ('scriptorium 4.0'). Keller and Kay both point out that it is not only the metaphor of the 'book of nature' that sets the background concept for reading and writing the genetic code but also the technological and practical dimensions of research, the information discourse in computer science and cybernetics and finally the political and social context of the cold war and the human genome project, which strongly influenced the history of biology in the middle of the twentieth century - and are contained, one could say encoded, in the metaphor of the genetic code $[71,73]$.

The historical origin of the genetic code metaphor is Schrödinger's influential book What is life? The Physical Aspect of the Living Cell, dating back to a homonymic series of lectures in Dublin and published in 1944 [103]. With his pioneering work, Schrödinger introduced the metaphor of the 'genetic code' and thereby significantly influenced the further history of modern molecular biology and genetics [52]. Blumenberg describes Schrödinger's metaphorical invention as an episode within a metaphorological history of the legibility of the world ([18], pp. 372-409). The genetic code, descended from the old script metaphor of the book of nature' - and today turning into a 'scriptorium 4.0'here fulfils the function of closing the gap between metaphor and model, i.e. the transition from initially struggling with different metaphorical models of explanation to a hypothetical scheme that drives scientific research and initiates a paradigm shift. According to Blumenberg, biochemistry and genetics were successful not least because Schrödinger's metaphorical idea was taken literally (ibid., pp. 376-379). This is obviously true for synthetic biology. Seventy years later, Venter held an anniversary lecture in Dublin with the title What is life? He described the conceptual background of his view of synthetic biology and what he thought he was actually doing by creating a bacterial cell: 'I describe DNA as the software of life and when we activate a synthetic genome in a recipient cell I describe it as booting up a genome, the same way we talk about booting up a software in a computer' [113]. Venter refers directly to Schrödinger's metaphor and reformulates it into computer terminology. In his view, he takes the metaphor of the genetic code literally and does not only see DNA as the software of life but also actually (re)writes this code. Based on his perspective on telling the story from reading to writing the genetic code, one could say that Venter's experiments are a demonstration of the innovative and revolutionary power of metaphors in scientific inquiry and technological developments - the genetic code metaphor was literally brought to life.

As we have illustrated throughout this paper so far, the technomorphic metaphors in the debate about life receive some criticism due to the risks of mystification, misuse or nonsense ('What Is the Meta for? Risks of Technomorphic Metaphors in Uncertain Situations'). Furthermore, the reductionist explanations of synthetic biology have been criticised insofar as they need to be substantially complemented if the aim is to grasp a more holistic understanding of life ('From Holism to Reduction and Far Beyond: Wide and Narrow Understandings of Life'). But what also often remains overlooked in the debate on 'life' is the other side of the coin: the naturalisation and reductionism that is already inherent to information technological speech. Even before any IT metaphor is applied to 'life', the IT-traversed terminology of 'booting', 'reading' or 'writing a code' contains a peculiar naturalisation of human communication which is criticised for instance by Janich from a languagecritical and culturalistic point of view. In a misleading way, the relations between information and life are turned upside down when it is argued that phrases like 'genetic information' are not anthropomorphic metaphors but rather realistic object-related descriptionsas in the aforementioned case of Venter. Here, not only is the term life used in a reductionist way; the computer scientific side of the coin - the terms 'information' or 'code' - also receives an inadequately naturalised connotation. In a strong naturalistic sense, information appears as if it were the object of natural history and therefore the object of biology, physics or chemistry ([69], pp. 106-107).

This misleading development overlooks the reality that information is not a natural fact. Information is rooted in the cultural praxis of communication and rests on human interactions such as dialogical speech. Talk about 'genetic information', and beliefs that information is the result of a natural process of evolution, run into a tension: How do you explain the fact that humans refer to 'life' or 'information' meaningfully in a social context, if information or life as such is only the result of natural history and therefore only a matter of natural facts? And this tension applies to the scientist herself: She would have to explain her own speech act of explaining the overarching naturalisation as an incident 
of natural evolution and not as an argument within the debates within a scientific community. Here, a critical perspective on the self-understanding of the researcher opens up also from a methodological point of view. (From a different point of view, in 'From (Proto)Type to Hype: an Argument for and Against the Pedagogical Side Effect of 'Living Machines", some critical ethical remarks on the pedagogical self-explication will be added as well.) Yet, as long as the metaphorical speech is made explicit and treated in a methodically adequate way, there remains no need to ban metaphorical speech about life or information in scientific engagement (ibid., pp. 111-112; [70], p. 610).

In a more traditional formulation, ethical problems arise at the related cutting edge between 'life'/'information' as descriptive terms and 'life'/'information' as value-laden reflexive concepts. Here the short-sighted jump from matters of fact to matters of human autonomy, morality or social practices can only be realised for the sake of Hume's Law ([68] Book 3, Part I, Section 1) or the so-called naturalistic fallacy [88]. The confrontation of 'life' and IT-traversed terminology on the other hand also makes an unexpected point, since it illustrates the power of 'life' as Burstword II. Here 'life' in its obviously wide meaning bursts the inadequate narrow understanding of information as a natural incident. IToriented terms are part of the technomorphic metaphors of life. Vice versa, 'life' can also be seen as a part of the anthropomorphic metaphors of information and therefore detonate the conceptual and disciplinary narrowing of information technologies, where its link to the human lifestyle of communication has been lost.

In the sense of methodologically controlled use, the innovative, paradigm-changing power of metaphors, combined with their critical and argumentative functions, relates exactly to the positive side of the story (which finds its negative counterpart in 'From Buzz to Fuzz: the Dangers of the Unclear and Metaphorical Use of 'Life"). Whereas in a methodologically noncontrolled way, metaphors quickly turn into fuzzy, foggy and buzzy clouds of ideological misuse, or everything and nothing (Burstword I), in a methodologically considered way they also support important inherent dynamics of processes of scientific investigation (Burstword II). What remains an open issue, which cannot be answered in this paper, is the question of the concrete ways in which the innovative use of metaphors can be methodologically controlled in all respects. Nor can we address the methodological and epistemological issue of investigating life in transdisciplinary research groups (with and without using fuzzy and folk concepts, buzzwords, metaphors of life or life as metaphor).

We now turn to the ethical aspect of discourses of life within and about synthetic biology. Several links to genuine ethical problems have been mentioned already, especially the conflict between matter of fact (empiricaldescriptive speech about life) and 'matter of ought' (normative-reflexive speech about life) that follows from the amalgamation between nature and culture in synthetic biology. This conflict might be avoided with a strict reductionist usage of 'life' (narrow understanding) in biology or an explicitly wide usage that is widespread in ethics, where life as a moral way of life is the genuine object of investigation. The crucial question is: Are we aware that 'living machines', 'artificial life' or 'genetic information' are metaphors for a limited treatment of life, which cannot be applied to human ways of life? After having emphasised the opportunities and pitfalls of reductionist and naturalised speech in synthetic biology, we turn to a self-critical view of ethics as well. Therefore, in the following section, we present some arguments related to ethical fallacies regarding a misleading ethical fundamentalism and even ethical pseudo-problems.

\section{From Buzz to False Alarm: Fallacies Regarding the Normative Effects of a Fabrication of Life}

Synthetic biology is concerned not only with living, in terms of disassembling, analysing and maybe modifying it but also and especially with engineering and creating life. Due to this technical and manufacturing paradigm, the whole emerging field of research is often presented as a kind of new technoscience that deals with the artificial creation of life in the laboratory or a similar working space [53, 90, 92]. Thereby, the term 'technoscience' itself can be seen as a metaphor not only for the intimate amalgamation of laboratory technologies and scientific research but also for the ethical nonneutrality of synthetic biology (we note that nonneutrality is a general characteristic of every technical praxis). There is no research practice without technical, constructive actions. And wherever humans act intentionally, ethical concerns, e.g. of responsibility, may potentially arise. In particular, next to the metaphorical issues, the more fundamental claim of 'fabricating life' 
is the especial focal point of concern and critique from an ethical perspective. Philosophers and ethicists who observe and assess the field are discussing one of the key issues of synthetic biology under the umbrella of the notion of 'life creation' [9, 22] - alongside 'life' and 'synthetic biology', this is now the third umbrella concept, this time in a genuine ethical context. As we have seen, the usage of life - as a fuzzy, foggy and buzzy Burstword I as well as folk concept, umbrella term, theoretical concept or methodologically explicated metaphor (Burstword II) - plays a crucial role in the ELSAdiscussion and in the public debate. Two main types of objections to the aim of creating life in an artificial way are advanced from an ethical perspective. The first objection refers to the conceptual dimension of the paradigm of life in synthetic biology. Here it can be argued that the awareness of the reductionist treatment of life increases the respect for real life in its many complex facets. At the same time, ethical problems are also linked to a growing practical complexity, which goes along with operational 'black-box' knowledge in technoscientific working groups. In this context, we combine the three umbrellas mentioned in this paper (life, synthetic biology and 'life creation', as the ethical one) and present an argument for how life as Burstword II also affects a reductionist understanding of ethical problems. The second objection refers to the more practical or consequentialist implications of the very concept of life and living. Here again in an outline of a concrete argumentative sequence, the function of 'life' as Burstword II can be illustrated with respect to its borderlines with the concept of 'machine'.

From Misguiding Simplification to Respectful Complexity: an Argument Regarding the Ethical Focus

As we have illustrated with respect to the current debate the very concept of life in synthetic biology arouses criticism and contradiction. Let us at this point reframe the first type of ethical objection and start with the assumption that it is feared that, when dealing with life forms, the dominant science-oriented paradigm of synthetic biology has negative consequences for the concept and understanding of life and living in general. According to that criticism, which addresses a sort of ontological question on a descriptive level, the methodological strategy of synthetic biology leads to problems on a conceptual level. Thus, synthetic biology's methodology, which is strongly shaped by the aforementioned pragmatic engineer's approach (see 'Engineering Under an Umbrella: Epistemology of Synthetic Biology and the Constructive Approach'), represents and reinforces epistemically a misguided reductionist conception of life. A very fundamental version of this objection highlights the fact that every arrangement and observation of living phenomena in an experimental manner, in an artificial setting like a laboratory, can reveal only a very special and limited view of and insight into life - which needs to be complemented by ethical reflections on cultural, political or social ways of life. In the background - once again — stands the difference between a wider Aristotelian understanding of life and a narrower and reductionist understanding in synthetic biology, as introduced in 'Life Is Not Life: Aristotle's Wide Concept of Life and the Current Condensation of Modern Thinking in Synthetic Biology'.

According to this view, experimental research in the laboratory - or a similar workspace-will never show what life 'as such' actually is-however, there might be no need for biologists to define life at all (see 'No Need to Argue, No Need for Definitions'). For this sceptical position, it is clear and almost selfexplanatory that life is always more than what a reductionist view or a view focused on some aspects of it could explain. Life-definition scepticism can thus support a holistic understanding of life that regards life as an elusive, holistic entity which can never be explained completely. Since there will always be an unattainable remainder, life holists often advance vitalistic interpretations of life (see 'From Opposition to Amalgamation: Natural and Cultural Life'). This critical position is not without merit: The idea of separating, disassembling and modularising living systems in small and smallest possible parts reinforces the critique of holistic life-definition sceptics. The tool kit pattern, the metaphor of life as a 'tool box' and the concept of the BioBricks illustrate that modularisation and standardisation of life are important aspects of the scientific approach to life. Such a view is incompatible with seeing life as a complex, whole and indivisible entity. From a holistic point of view, concentrating on the minimal preconditions of life's functioning as an epistemic way to figure out what life is, as top-down synthetic biology proposes, is thus misguided from the beginning. Ignoring life's specific intangibility by claiming to exercise total controllability is also condemned to failure. Life holists argue that these failures rest on a misapprehension of what life is. 
Yet it is doubtful if the methodological reductionism in synthetic biology can be connected with the comprehensive claim of explaining life 'as such'. As mentioned in 'No Need to Argue, No Need for Definitions', a definition of life as such is not seen as necessary from the perspective of practitioners. The reductionist view of life is introduced and established for specific purposes, for purposes of building and engineering, not for apprehending the essence of life or for explaining life in its full range and complexity. (There are, however, exceptions, such as Venter's statements that advance an overarching understanding of life with reductionist means; see 'What Is the Meta for? Risks of Technomorphic Metaphors in Uncertain Situations' and 'Life as Theoretical Object of Synthetic Biology') There are at least two facts that can count as an indication for this. First, the importance of biosafety issues in synthetic biology is probably not denied by any serious scientist in the field [99]. This illustrates that there is a strong awareness concerning the limits of controlling living entities. And second, there are scientists in synthetic biology who are indicating a necessary broadening of the range of their own activity by using the term 'tinkering' $[10,105]$. Thereby, the methodological procedure is to be supplemented with the principle of trial and error, which comprises a kind of reacting and cooperating with the living material and its contingency, rather than determining and commanding it. In this, the 'tinkering synthetic biologists' are also acknowledging certain predictive limits that emerge from working with living objects in principle. In this sense, the designing, synthesising and engineering of artificial life forms can only be successful if it reckons with a certain internal dynamics of the living [63]. Regarding this dimension of a certain natural originality and obstinacy or self-will, one could instead come to the opposite conclusion: by doing synthetic biology, the respect and estimation of the living is reinforced rather than weakened.

This insight correlates to another somehow paradoxical observation: due to its bottom-up, trial-anderror and tinkering character, it can be argued that, under the umbrella of synthetic biology, practical complexity is in fact increasing instead of being reduced. Nordmann, for instance, has shown that the many very pragmatic tools and procedures in synthetic biology cause a multifaceted range of operational knowledge that cannot be explained with the analytical approach of systems biology. Instead, the non-theorised practical 'black-box' knowledge plays an ever more important role [92]. Both the respect for life and for operational and technical skills are reinforced. Here all three 'umbrellas' - to use this metaphor as another methodological illustration-meet in a remarkable way: (1) Both reinforcements mentioned are related to the many approaches that are practically performed under the umbrella of synthetic biology. (2) 'Life' remains an umbrella since it captures the reductionist, theoretically controllable meaning of 'life' as well as the diverse aspects of 'life' that are the object of practical engagement without a perfect logical or analytical explanation ('black-box' character, tinkering). (3) The ethical umbrella of 'life creation' relates concretely to the respect for 'life' in practical engagement, and here especially to the responsibility that is inherent in all human (intentional) actions. Methodologically, 'life' serves as Burstword II when the reductionist understanding of life is made explicit and is either sceptically deconstructed and/or leads to a broadening of the disciplinary or conceptual focus, wherever this focus remains inadequate to its object. Concretely, this means that for the meeting point of the three umbrellas in this line of argumentation, 'life' is bursting the narrow disciplinary focus of systems biology as well as analytic top-down approaches and expanding it to the realm of technoscientific laboratories in synthetic biology. In conclusion, both an epistemic shift from theoretical top-down knowledge to practical bottom-up knowledge and a shift within the ethical problematisation can be observed: the reductionist understanding of 'life' does not primarily remain the object of a fundamentally ethical critique. Instead, it illustrates the need for specific and applied ethical assessments of concrete research actions in the field. 'Life creation' appears to be a Burstword II insofar as it-literally-detonates a misleading ethical fundamentalism or imprecise reductionist focus - or even more, maybe also, ethical pseudo-problems. Ethical assessment becomes more complex insofar as it is required to bring a complex technoscientific praxis into focus. Philosophical language critique as it is applied to the self-expression of the researcher and the restraint of any naturalised speech when it comes to human social ways of life (Hume's Law or Moore's naturalistic fallacy) are concrete tools for the applied ethical assessment ('Reveal a Scriptorium 4.0: Linguistic and Biological Innovations of the 'Genetic Code' Metaphor'). 
From (Proto)Type to Hype: an Argument for and Against the Pedagogical Side Effect of 'Living Machines'

A second ethical objection is related to another line of argumentation, which we want to portray with an emphasis on reservations regarding a certain attitude toward living objects. Here the technologically deterministic paradigm in synthetic biology of controlling, constructing and creating the living cannot only be criticised in a descriptive or ontological way as a fundamentally misguided research approach; questionable effects in normative regards might also be criticised. The assumption is that, according to the dominant premise in the field of synthetic biology, living beings can be taken apart in minimal functional components out of which completely novel living systems can be reassembled from scratch, independently of natural standards. Besides the descriptive objections, the engineering approach of modularisation and standardisation, of partition and building, of deconstructing and reconstructing, obviously has practical implications. These practical implications concern the ways of doing synthetic biology and give occasion to criticism on a prescriptive level. Doing science under the label of synthetic biology always implies a certain mode of working with living entities. This mode of handling the living is strongly shaped by the technical, productional and instrumental paradigm (see 'Engineering Under an Umbrella: Epistemology of Synthetic Biology and the Constructive Approach') that determines synthetic biology and thus leads to ethical problems. The disputable norms of action are consequences of the understanding of the living. By seeing life as a result of a technological process of production, which is activated for arbitrary purposes, a manipulative and instrumental approach to the outcome of the production is predefined. Inevitably, the products of synthetic biology — which are by definition alivewould thereby be subject to a way of handling as inanimate artefacts that does not acknowledge any value for its own sake [48]. Synthetic biology (and biotechnology in general) could be confronted with such an attitude of a technical-instrumental use that is not compatible with living objects in principle because it does not acknowledge any intrinsic value the living may have. Thus, even the designing and engineering of microorganisms from scratch means a devaluation of these basal life forms.

This apprehension of instrumentalisation and debasement of life and natural values goes beyond particular living systems. In further consequence - it might be argued - it leads to negative retroaction and a certain ethical impact on how life in general is understood and valued. In a temporal respect, this fear concerns effects in the present as well as in the future. Following this, as a current impact, it is assumed that if low or rudimentary forms of living organisms are treated like non-living material without any intrinsic value, as they belong to the sphere of the living, the status of other living objects - that are not only bacteria or yeast — could also diminish as a (pedagogical) side effect. This would imply a weakening of the respect for higher forms of life that are usually regarded as worthy of respect and protection. If man is practising the instrumentalisation and exploitation of low life forms, and gets used to it, the moral barrier to the inclusion of higher organisms in the paradigm of technical-instrumental engineering and fabrication decreases. In the course of a process of habituation to the usage of the living, even life forms that are commonly worth protecting would, step by step, lose their state of intrinsic value, and the morally dangerous effect of a general brutalisation is expected. Following that line of slippery-slope argumentation, it can be predicted, as a further consequence, that this development would finally lead, by implication, to changes in the moral appreciation and status of humans. Arguments like these are already known from the debates in environmental ethics, where non-human natural environments receive a 'pedagogical function' also for social interactions: How we treat other humans is trained by interacting with the non-human environment-which receives a somehow prototype status ([51], pp. 132$135)$. In addition, a potentially related pedagogical function also applies to metaphors that transport this or the following line of argumentation - with all its advantages and disadvantages (see 'What Is the Meta for? Risks of Technomorphic Metaphors in Uncertain Situations' and 'From Radiation to Rehabilitation: the Positive Methodological Functions of Metaphors of Life and Life as Metaphor').

However, the fear could arise of certain dubious effects on the (pedagogical) self-conception of humanity if synthetic biology expands a technical-instrumental handling to higher forms of life. This idea contains a shift from the anthropological term of the homo faber, who is 'only' manipulating existing organisms, to a homo creator, who reinvents nature and is therefore at risk of overestimating his comprehension of nature ([20]; see also [94]). It is also important to note here 
that the abovementioned self-conception of humanity is different to the linguistic self-conception, including the semantic side effect that has been mentioned with respect to language-critical analysis of metaphorical speech (see 'Reveal a Scriptorium 4.0: Linguistic and Biological Innovations of the 'Genetic Code' Metaphor'). But again, these objections are to be examined for their part. Concerning negative implications and (pedagogical) side effects of dealing with life as an engineering and manufacturing matter, one has to differentiate between two levels of argumentation: First, the assumption that the purposeful designing and engineering of living systems implies that these low life forms are treated as mere non-living material; second, the fear that this kind of objectifying handling leads to negative and brutalising (pedagogical) side effects. The first assumption seems to be only an assertion that lacks the proof of its necessity. Merely because synthetic biology follows the strong technical character of engineering and production, it does not need to devaluate its objects and treat them like non-living material. But even if one might concede a certain tendency to such an approach, one would have to show why this should be a normative risk specific to synthetic biology, one that does not already exist in the case of conventional biotechnologies or genetic engineering - or even the mechanistic view of life since the seventeenth century (see 'From Opposition to Amalgamation: Natural and Cultural Life'). Similarly, the effect of brutalisation, of an expansion of a devaluating and careless handling from lower life forms to higher stages, seems to be more an exaggerated fear than a probable and realistic consequence. Why should the systematic design and fabrication and an instrumentalised usage of yeast cells and bacteria lead to a problematic devaluation of higher life forms or even have any consequences for the selfunderstanding of man?

In the case of these lower forms of life, the commonality with plants, animals and particularly humans is only comprehensible on an abstract level. We could understand or accept that bacteria are part of the same dimension - being alive - as we are, only if we 'learn' biological facts. There are no perceptible properties that connect us with yeast cells - and not to forget the important language-critical separation between matter of fact and 'matter of ought' (!). In this regard, 'living machines' as an output of synthetic biology are in ethical terms actually more machines than living entities for us. As mentioned in 'Engineering Under an Umbrella:
Epistemology of Synthetic Biology and the Constructive Approach', Toepfer argues that synthetic biology will primarily 'broaden our concept of machines' and not promote our mechanistic view of life ([111], p. 82). If this is true, we find again an example of 'life' as Burstword II: the disciplinary and conceptual focus on machines is extended due to the limits of a meaningful application of the word 'life'. This conclusion might appear somehow surprising since a narrow view on life as such is not expanded. What happens here can be seen as a methodological — not ontological - treatment of the Aristotelian nature-culture distinction. By adjusting the terminological borderline, a semantic drawback of 'life' leads in this case to an expansion of 'machine'-there is, so to speak, a semantic undertow effect or, more figuratively, an indirect backdoor bursting II. Even if there are reasons to reject an ontological nature-culture distinction as it is currently discussed (see ('From Opposition to Amalgamation: Natural and Cultural Life'), another methodological advantage of this dualism has been emphasised with respect to Janich [69]. The dualism stands for the urgent methodological need for differentiation between matter of fact (empiricaldescriptive talking about life or machines) and 'matter of ought' (normative-reflexive talking about life or machines). Precise ethical assessment of synthetic biology requires the explicit and clear conceptualisation of the field, which also includes open eyes for the empirical reality in the laboratory and its products. However, from a morally relevant perspective, these objects are much further away from higher organisms, so that it is absolutely not convincing that a certain way of handling bacteria in the petri dish would extend to our attitude to mammals, for example. Not to mention, our own selfunderstanding and self-evaluation. Most notably, it is unclear why this of all things should occur here in the case of synthetic biology, if it has not (already) happened after decades and centuries of factory farming and industrial meat production.

As a critical appraisal of the outlined types of conceptual criticism against synthetic biology shows, the concept of life is a highly loaded and precarious notion which indeed provokes controversial debate, but which is thereby mainly misleading and irritating. Its remarkable appeal and powerful ability to transport indistinct fears and some incoherent apprehension are indicative of another function of the usage of 'life' in the debate. Criticism regarding synthetic biology's concept of life can be understood as the expression of a conceptual 
uncertainty and a corresponding uneasiness resulting from the transgression and blurring of terminological and ontological boundaries that seemed so far unalterable (life as Burstword I; see 'From Buzz to Fuzz: the Dangers of the Unclear and Metaphorical Use of 'Life"). These boundaries comprise the distinction between technology and nature, between products and living beings, between natural and artificial, etc. Thereby, it must be emphasised that this uneasiness can potentially have a big societal impact, because it does exist (not only among ethicists and biocentrists). Moreover, regarding its theoretical and conceptual impact, that uneasiness should lead to questioning the conceptual desire or demand for clear and definite distinctions and boundaries - especially if one is dealing with thresholds between nature and technology, as is to a considerable degree the case with synthetic biology. Here we must also clearly confess that the borderlines between life as - in our terms-Buzzword I and Buzzword II are blurry as well, since it depends heavily on the genuine human cultural praxis of word use. 'Life' in synthetic biology remains the object of ongoing challenges for current rational critical debates including ethical assessment and sceptical self-critique.

\section{From Boost to Burst: Summary and Outlook}

Our paper had various aims: We combined a review of significant positions in the debates about life with the aim to rethink its object: the use of 'life' in synthetic biology. We thus created an account from buzz to burst in six steps. The phenomenon of bursting - which is our main thesis - can be applied to the semantic, conceptual and disciplinary framework in which the term 'life' is used. As with many terms, the use of 'life' is not static. It can be used in multiple ways, for instance in metaphorical speech or as a buzzword for funding acquisition. In scientific and also technoscientific contexts, the clarification of key concepts is of certain relevance in order to enable precise and successful communication and assessment. To this extent, the bursting, transcending or blurring of meaningful wording obviously contains certain risks or even dangers. We introduced the term Burstword I in order to illustrate the risky treatment of terminology, which in a non-methodical way can lead to something like an everything and nothing situation-literally, the detonation of semantic precision by creating fuzzy, foggy and buzzy clouds of nonsense. This Burstword I diagnosis does not only apply to 'life' in synthetic biology. In the end, it is related to any kind of arbitrary treatment of words, including unclear and misleading metaphors. Here it should not be overlooked that Burstword (I and $I I$ ) is a metaphor itself, with all the typical pros and cons of metaphorical speech.

What we call Burstword II is a functionality that can be found in many scientific terms - it is not exclusively reserved for 'life' in synthetic biology. We differentiated between two ways of bursting with a primary focus on the reconstruction of 'life' and its specific Burstword II characteristic. A boosted examination of the term 'life' and its usage can lead to a better understanding of in what sense it could fulfil its function of bursting conceptualisations or disciplinary foci in a productive sense-from boost to burst, so to speak. In conclusion, to briefly summarise: 'Life' as Burstword II

1. is the opposite of Burstword I since it describes a methodologically controlled use of 'life',

2. involves but is not limited to the innovative and cognitive function of metaphors in the tradition of Black, Kuhn and other authors,

3. is therefore itself a metaphor for this particular kind of metaphorical speech (see also the Boydian question 'what is metaphor a metaphor for?' [26],

4. includes following the demand that it is (as with other metaphors) explicitly treated as metaphor...

5. ...with the concrete function-besides innovation, paradigm changes etc. —of widening the conceptual and/or disciplinary foci, wherever the object/ problem requires this,

6. in conclusion, can be interpreted as a concept for reflection or even as a transdisciplinary research principle.

In order to demonstrate how this aspiration could be realised from a philosophical point of view in both a review-like and systematic manner,

1. the historical background has been reconstructed in a language-critical way by revealing three concrete conceptual characteristics of 'life', and with the aim to systematically better understand the use of 'life' (in 'Life Is Not Life: Aristotle's Wide Concept of Life and the Current Condensation of Modern Thinking in Synthetic Biology'): 

A. the differences between and the clash of the wide and narrow understandings,
B. the question of separation or amalgamation of nature and culture,
C. its conceptual mechanisation since the seven- teenth century in relation to the constructive, engineering approach of synthetic biology today,

2. aspects of their (1) impact on current debates and some main approaches of using 'life' between buzzword, folk, and theoretical concept have been illustrated (in 'Life Is Not Life: Aristotle's Wide Concept of Life and the Current Condensation of Modern Thinking in Synthetic Biology' and 'From Buzz to Fuzz: the Dangers of the Unclear and Metaphorical Use of 'Life"),

3. the pros and cons of metaphorical speech and technomorphic metaphors in the field have been summarised, also with the incentive to illustrate the word use we address with the distinction between Burstword I and Burstword II (in 'From Buzz to Fuzz: the Dangers of the Unclear and Metaphorical Use of 'Life" and "From Radiation to Rehabilitation: the Positive Methodological Functions of Metaphors of Life and Life as Metaphor').

4. trademarks of the research praxis and epistemic characteristics of synthetic biology between theoretical science, engineering and technoscientific tinkering have been briefly reconstructed (in 'From Buzz to Boost: Naturalisation of Life and Its Methodological Reduction in Synthetic Biology' and 'From Misguiding Simplification to Respectful Complexity: an Argument Regarding the Ethical Focus'),

5. three concrete examples have been included at the end of the paper in order to make more clear how 'life' as Burstword II can motivate constructive thinking out of the box since it

A. bursts a naturalised understanding of 'information' in IT if metaphors like 'genetic information' or 'genetic code' are reverse-reinterpreted with regard to the wide meaning of 'life', including the human way of life/conduct/behaviour of dialogical communication (including as an example the language critique of Janich in 'Reveal the Revolution: Methodologically Controlled use of Metaphors as Metaphors'),
B. broadens the ethical focus to the manifold praxis of technoscientific tinkering and concrete analyses of growing practical complexity instead of limiting the assessment to a worldly innocent fundamentalism (by discussing Nordmann, Schwille and other authors in 'From Misguiding Simplification to Respectful Complexity: an Argument Regarding the Ethical Focus'),

C. enables an argumentative rejection of side effects regarding the pedagogical self-conception of humanity and instead leads to a reversed expansion of the dialectically linked concept of machine (with respect to the analysis of Boldt, Toepfer and others in 'From (Proto)Type to Hype: an Argument for and Against the Pedagogical Side Effect of 'Living Machines").

At the end of this paper, we want to emphasise the tentative and open character of the systematic aim: the attempt to think out of the box by dissecting and reframing the debate under the umbrella of what we call Burstword II. Since this idea is not yet fully developed - a typical trademark of ongoing researchwe want to raise some open questions that we touched on indirectly but could not answer in this paper. We hope that our paper motivates further investigations in this direction:

1. We tried to capture the three most important ones, but have not been able to present an entire collection of all possibly related historical issues: What else is significant for the concept of 'life' and its methodical burst function?

2. What are the concrete ways in which the innovative use of metaphors can be methodologically controlled in detail? Only by explication or language critique? Which role does for instance professional training in research groups play? Is it a growing necessity to bring philosophical language critique into an R\&D position? If yes, how could or should this be realised?

3. Another follow-up question is the one about methodology and epistemology of transdisciplinary research where 'life' is seen as a common interest despite disciplinary differences. Is the burst function a primary requirement in order to open up the disciplinary expertise of each member and then to 
combine it in a real multidisciplinary synthesis (which is more than parallel interdisciplinary work with isolated methods)? If yes, are there examples in other fields like economy or agile IT project management that could help to better understand the concrete implementation?

4. Does 'life' as Burstword II affect metaphorological investigations and add another genuine transdisciplinary perspective to the already discussed functions of metaphors? If yes, how?

5. At several points, we referred to the self-conceptualisation of humanity, including the selfunderstanding of researchers, as semantic and pedagogical issue. These perspectives lead to additional questions: What kinds of selfunderstandings relate to the use of 'life' in synthetic biology? What are their characteristics and in what way could they affect the use of 'life' as Burstword II? What can we learn about the social role of scientists?

6. The same is true for side effects as well. We presented an argument against the existence of a certain form of pedagogical side effect, but this does not mean that there are no side effects at all. What are other side effects of the use of 'life' in synthetic biology, how can they be classified and what are the results of its further ethical evaluation?

7. Within the narrative of this paper the umbrella status of three concepts has been discussed: life, synthetic biology and 'life creation' as an ethical concept. Is Burstword II in the end one more umbrella term or umbrella metaphor? Selfcritically asking: could another umbrella carry any straightforward significance for the debate? Can it be successfully applied as a tool to analyse the concrete use of 'life' and/or support the methodical explication of metaphors as metaphors?

8. In what sense could 'life' be a Burstword II in other fields like robotics, artificial intelligence or computer-based artificial life?

9. What are the results if other scientific or technoscientific concepts like 'information' or 'nature' are critically analysed as Burstword II?

10. Do we find the concept of life as Burstword II also in the political understanding of current societies? Does this language-philosophical tool enable us to revise and revaluate the popular concept of biopolitics?
Acknowledgements We would like to thank the organisers of the summer school Analyzing the Societal Dimensions of Synthetic Biol$o g y$, Kristin Hagen, Margret Engelhard and Georg Toepfer, who brought us together in Berlin - already five years ago — and motivated, together with Stefanie Seitz, our further joint research on life in synthetic biology; also the reviewers of an earlier version of this paper who provided important critical feedback and suggested several improvements during the review process; and finally Christopher Coenen for patience, further feedback and constant encouragement.

Funding Information Open access funding provided by University of Vienna.

Open Access This article is licensed under a Creative Commons Attribution 4.0 International License, which permits use, sharing, adaptation, distribution and reproduction in any medium or format, as long as you give appropriate credit to the original author(s) and the source, provide a link to the Creative Commons licence, and indicate if changes were made. The images or other third party material in this article are included in the article's Creative Commons licence, unless indicated otherwise in a credit line to the material. If material is not included in the article's Creative Commons licence and your intended use is not permitted by statutory regulation or exceeds the permitted use, you will need to obtain permission directly from the copyright holder. To view a copy of this licence, visit http://creativecommons.org/licenses/by/4.0/.

\section{References}

1. Acevedo-Rocha CG (2016) The synthetic nature of biology. In: Hagen K, Engelhard M, Toepfer G (eds) Ambivalences of creating life. Societal and philosophical dimensions of synthetic biology. Springer, Switzerland, pp 9-53

2. Achatz J (2014) Framing 'Nature' - Synthetische Biologie schreibt (ihre) Geschichte. In: Achatz J, Knoepffler N (eds) Lebensformen - Leben Formen. Ethik und Synthetische Biologie. K\&N, Würzburg, pp 83-100

3. Achatz J, O'Malley M, Kunzmann P (2012) Der Stand der ethischen Diskussionen um Synthetische Biologie. In: Köchy K, Hümpel A (eds) Synthetische Biologie. Entwicklung einer neuen Ingenieurbiologie? Wis Verl, Dornburg, pp 165-190

4. Althoff J (2005) zôê / Leben. In: Höffe O (ed) AristotelesLexikon. Kröner, Stuttgart, pp 614-616

5. Arbib MA, Hesse MB (1990) The construction of reality. Cambridge University Press, Cambridge

6. Aristoteles (2012) Politik (trans., ed. and introduced by E. Schütrumpf). Felix Meiner, Hamburg

7. Aristoteles (2017) Über die Seele / De Anima (trans., ed. and introduced by C. Corcilius). Felix Meiner, Hamburg

8. Bedau M (2010) The power and the pitfalls. Nature 465:422

9. Bedau M (2011) The intrinsic scientific value of reprogramming life. Hast Cent Rep 41(4):29-31

10. Benner S, Yang Z, Chen F (2011) Synthetic biology, tinkering biology, and artificial biology. What are we learning? C R Chim 14:372-387 
11. Berggren D (1962) The use and abuse of metaphor, I. Rev Metaphys 16(2):237-258

12. Berggren D (1963) The use and abuse of metaphor, II. Rev Metaphys 16/3:450-472

13. Beuttler U (2011) Strukturelemente und Wert des Lebens theologisch-hermeneutische und ethische Überlegungen zum Lebensbegriff der Synthetischen Biologie. In: Dabrock P, Bölker M, Braun M, Ried J (eds) Was ist Leben - im Zeitalter seiner technischen Machbarkeit? Verlag Karl Alber, Freiburg, pp 277-305

14. Billerbeck S, Panke S (2012) Synthetische Biologie Biotechnologie als eine Ingenieurswissenschaft. In: Boldt J, Müller O, Maio G (eds) Leben schaffen? Philosophische und ethische Reflexionen zur Synthetischen Biologie. Mentis, Paderborn, pp 19-40

15. Black M (1962) Models and metaphors. Cornell University Press, Ithaca, NY

16. Black M (1979) More on metaphor. In: Andrew O (ed) Metaphor and thought. Cambridge University Press, Cambridge, pp 19-41

17. Blumenberg H (1979) Schiffbruch mit Zuschauer. Suhrkamp, Frankfurt am Main

18. Blumenberg H (1986) Die Lesbarkeit der Welt. Suhrkamp, Frankfurt am Main

19. Boldt J (2012) "Leben" in der Synthetischen Biologie. Zwischen gesetzförmiger Erklärung und hermeneutischem Verstehen. In: Boldt J, Müller O, Maio G (eds) Leben schaffen? Philosophische und ethische Reflexionen zur Synthetischen Biologie. Mentis, Paderborn, pp 177-191

20. Boldt J (2013) Life as a technological product. Philosophical and ethical aspects of synthetic biology. Biol Theory 8:391-401

21. Boldt J (2018) Machine metaphors and ethics in synthetic biology. Life Sci Soc Pol 14:1-13. https://doi.org/10.1186 /s40504-018-0077-y

22. Boldt J, Müller O (2008) Newtons of the leaves of grass. Nat Biotechnol 26(4):387-389

23. Boldt J, Müller O, Maio G (2009) Synthetische Biologie. Eine ethisch-philosophische Analyse. BBL, Bern

24. Bölker M (2011) Revolution der Biologie? Ein Überblick über Voraussetzungen, Ansätze und Ziele der Synthetischen Biologie. In: Dabrock P, Bölker M, Braun M, Ried J (eds) Was ist Leben - im Zeitalter seiner technischen Machbarkeit? Verlag Karl Alber, Freiburg, pp 27-41

25. Bölker M, Engelhard M, Budisa N (2016) Synthetic biology. Diverse layers of live. In: Engelhard M (ed) Synthetic biology analysed. Tools for discussion and evaluation. Springer, Switzerland, pp 27-50

26. Boyd R (1993) Metaphor and theory change. What is "metaphor" a metaphor for? In: Ortony A (ed) Metaphor and thought, 2nd edn. Cambridge University Press, Cambridge, pp 481-532

27. Brenner A (2007) Leben. Eine philosophische Untersuchung. BBL, Bern

28. Brenner A (2012) Leben leben und Leben machen. Die Synthetische Biologie als Herausforderung für die Frage nach dem Lebensbegriff. In: Bold J, Müller O, Maio G (eds) Leben schaffen? Philosophische und ethische Reflexionen zur Synthetischen Biologie. Mentis, Paderborn, pp 105-120
29. Brukamp K (2011) Lebenswelten formen. Synthetische Biologie zwischen Molekularbiologie und Ingenieurtechnologie. In: Dabrock P, Bölker M, Braun M, Ried J (eds) Was ist Leben - im Zeitalter seiner technischen Machbarkeit? Verlag Karl Alber, Freiburg, pp 61-74

30. Budisa N (2012) A brief history of the "life synthesis". In: Hacker J, Hecker M (eds) Was ist Leben? Wiss. Verl.-Ges, Stuttgart, pp 99-118

31. Busche H (2005) psychê / Seele. In: Höffe O (ed) Aristoteles-Lexikon. Kröner, Stuttgart, pp 505-513

32. Caplan A (2010) The end of vitalism. Nature 465:423

33. Ceccarelli L (2018) CRISPR as agent. A metaphor that rhetorically inhibits the prospects for responsible research. Life Sci Soc Pol 14. https://doi.org/10.1186/s40504-0180088-8

34. Cho MK, Magnus D, Caplan AL, McGee D, Ethics of Genomics Group (1999) Ethical considerations in synthesizing a minimal genome. Science 286:2088-2090

35. Church G (2010) Not let's lower costs. Nature 465:422

36. Cleland CE (2019) The nature of life. Classical and contemporary perspectives from philosophy and science. Cambridge University Press, Cambridge

37. Condit CM, Condit DM (2001) Blueprints and recipes. Gendered metaphors for genetic medicine. J Med Humanit 22/1:29-39

38. Coyne L (2019) The ethics and ontology of synthetic biology. A Neo-Aristotelian Perspective. NanoEthics (online first, 13 pages). https://doi.org/10.1007/s11569-01900347-2

39. Cserer A, Seiringer A (2009) Pictures of synthetic biology. Syst Synth Biol 3:27-35

40. Dawkins R (2008) Geschichten vom Ursprung des Lebens. Ullstein, Berlin

41. De Vriend H, Walhout B, van Est R (2007) Constructing life - the world of synthetic biology. Rathenau Institut, Den Haag

42. Debatin B (1995) Die Rationalität der Metapher. Eine sprachphilosophische und kommunikationstheoretische Untersuchung. Dissertation, Technische Universität Berlin

43. Deplazes A, Huppenbauer M (2009) Synthetic organisms and living machines. Positioning the products of synthetic biology at the borderline between living and non-living matter. Syst Synth Biol 3:55-63

44. Deplazes-Zemp A (2012) The conception of life in synthetic biology. Sci Eng Ethics 18:757-774

45. Döring M (2018) Synthetic biology in the German press. How implications of metaphors shape representations of morality and responsibility. Life Sci Soc Pol 14. https://doi. org/10.1186/s40504-018-0079-9

46. Editorial (2007) Meanings of 'life'. Synthetic biology provides a welcome antidote to chronic vitalism. Nature 447: 1031-1032

47. Eichinger T (2016a) Debasement of life? A critical review of some conceptual and ethical objections to synthetic biology. In: Hagen K, Engelhard M, Toepfer G (eds) Ambivalences of creating life. Societal and philosophical dimensions of synthetic biology. Springer, Switzerland, pp 267-274

48. Eichinger T (2016b) Production biology. Elements and limits of an action paradigm in synthetic biology. In: 
Boldt J (ed) Synthetic biology. Metaphors, worldviews, ethics, and law. Springer VS, Wiesbaden, pp 61-70

49. Engelhard M, Bölker M, Budisa N, Hagen K, Illies C, Pardo-Avellaneda R, Toepfer G, Winter G (2016) The new worlds of synthetic biology-synopsis. In: Engelhard M (ed) Synthetic biology analysed. Tools for discussion and evaluation. Springer, Switzerland, pp 1-25

50. Falkner D (2016) Metaphors of life. Reflections on metaphors in the debate on synthetic biology. In: Hagen K, Engelhard M, Toepfer G (eds) Ambivalences of creating life. Societal and philosophical dimensions of synthetic biology. Springer, Switzerland, pp 251-265

51. Fenner D (2010) Einführung in die Angewandte Ethik. UTB, Tübingen

52. Fischer EP, Mainzer K (eds) (1990) Die Frage nach dem Leben. Pieper, München

53. Funk M (2016) Synthetic biology between engineering and natural science. A hermeneutic methodology of laboratory research practice. In: Hagen K, Engelhard M, Toepfer G (eds) Ambivalences of creating life. Societal and philosophical dimensions of synthetic biology. Springer, Switzerland, pp 313-323

54. Funk M (2018) Gebrauchsanleitungen für „lebende Maschinen"? - Synthetische Biologie zwischen Ingenieur und Anwender. In: Engelschalt J, Maibaum A, Engels F, Odenwald J (eds) Schafft Wissen. Gemeinsames und geteiltes Wissen in Wissenschaft und Technik. SSOAR, pp 43-67. pid:nbn-resolving.org/urn:nbn:de:0168-ssoar58220-7

55. Gayon J (2010) Defining life: synthesis and conclusions. Orig Life Evol Biosph 40:231-244

56. Gibson DG, Glass JI, Lartigue C, Noskov VN, Chuang RY, Algire MA, Benders GA, Montague MG, Ma L, Moodie MM, Merryman C, Vashee S, Krishnakumar R, AssadGarcia N, Andrews-Pfannkoch C, Denisova EA, Young L, Qi ZQ, Segall-Shapiro TH, Calvey CH, Parmar PP, Hutchison CA III, Smith HO, Venter JC (2010) Creation of a bacterial cell controlled by a chemically synthesized genome. Science 329:52-56

57. Goodman N, Elgin CZ (1988) Reconceptions in philosophy and other arts and sciences. Routledge, London

58. Grunwald A (2011) Einführung: »Technik und Leben - zur neuen philosophischen Aktualität eines klassischen Themas«. In: Gethmann CF (ed) Lebenswelt und Wissenschaft. XXI. Deutscher Kongress für Philosophie Kolloquiumsbeiträge. Meiner, Hamburg, pp 113-122

59. Grunwald A (2012) Technikzukünfte als Medium von Zukunftsdebatten und Technikgestaltung. KIT, Karlsruhe

60. Hadot P (1980) Leben. I. Antike. In: Ritter J, Gründer K (eds) Historisches Wörterbuch der Philosophie (Vol. 5: LMn). Schwabe, Basel, pp 52-56

61. Hagen K, Engelhard M, Toepfer G (2016a) Editorial. Ambivalences in societal and philosophical dimensions of synthetic biology. In: Hagen K, Engelhard M, Toepfer G (eds) Ambivalences of creating life. Societal and philosophical dimensions of synthetic biology. Springer, Switzerland, pp 1-8

62. Hagen K, Engelhard M, Toepfer G (eds) (2016b) Ambivalences of creating life. Societal and philosophical dimensions of synthetic biology. Springer, Switzerland
63. Heinemann M, Panke S (2006) Synthetic biology - putting engineering into biology. Bioinformatics 22:2790-2799

64. Heinemann G, Timme R (eds) (2016) Aristoteles und die heutige Biologie. Vergleichende Studien. Verlag Karl Alber, Freiburg

65. Hesse MB (1970) Models and analogies in science, 2nd edn. Notre Dame University Press, Notre Dame, IN

66. Hirsch Hadorn G, Biber-Klemm S, GrossenbacherMansuy W, Hoffmann-Riem H, Joye D, Pohl C, Wiesmann U, Zemp E (2008) The emergence of Transdisciplinarity as a form of research. In: Hirsch Hadorn G, Hoffmann-Riem H, Biber-Klemm S, Grossenbacher-Mansuy W, Joye D, Pohl C, Wiesmann U, Zemp E (eds) Handbook of transdisciplinary research. Springer, Berlin,pp 19-39

67. Homberger DG (1998) Was ist Biologie? In: Dally A (ed) Was wissen Biologen schon vom Leben? Loccumer Protokolle, Loccum, pp 11-28

68. Hume D (1739/1888) Treatise of human nature. https://en. wikisource.org/wiki/Treatise_of_Human_Nature. Accessed 01 Sept 2019

69. Janich P (2006) Was ist Information? Kritik einer Legende. Suhrkamp, Frankfurt am Main

70. Janich P (2008) Information. In Mittelstraß J (ed) Enzyklopädie Philosophie und Wissenschaftstheorie (Vol. 3 G-Inn),2nd ed. (revised). Metzler, Stuttgart, pp 609-611

71. Kay LE (2000) Who wrote the book of life? A history of the genetic code. Stanford University Press, Stanford

72. Kearnes M, Kuch D, Johnston A (2018) How to do things with metaphors. Engineering life as hodgepodge. Life Sci Soc Pol 14. https://doi.org/10.1186/s40504-018-0084-z

73. Keller EF (2002) The century of the gene. Harvard University Press

74. Knuuttila T, Loettgers A (2017) What are definitions of life good for? Transdisciplinary and other definitions in astrobiology. Biol Philos 32(6):1185-1203

75. Köchy K (2012) Zum Verhältnis von Natur und Technik in der Synthetischen Biologie. In: In Bold J, Müller O, Maio $\mathrm{G}$ (eds) Leben schaffen? Philosophische und ethische Reflexionen zur Synthetischen Biologie. Mentis, Paderborn, pp 155-175

76. Kuhn TS (1993) Metaphor in science. In: Ortony A (ed) Metaphor and thought, 2nd edn. Cambridge University Press, Cambridge, pp 533-542

77. Lakoff G, Johnson M (2003) Metaphors we live by. University of Chicago Press, Chicago

78. Leatherdale WH (1974) The role of analogy, model, and metaphor in science. Elsevier, Amsterdam

79. Loos E (2015) Biologische Konzepte von „Leben“ und die Synthetische Biologie. In TTN edition, 1/2015, pp 29-47

80. Machery E (2012) Why I stopped worrying about the definition of life... and why you should as well. Synthese 185(1):145-164

81. Mainzer K (2011) Eine Wissenschaft vom Künstlichen und Komplexen. Synthetische Biologie als Technikwissenschaft des 21. Jahrhunderts. In: Pühler A, Müller-Röber B, Weitze MD (eds) Synthetische Biologie. Die Geburt einer neuen Technikwissenschaft. Springer, Berlin, pp 111-127 
82. Marliére P (2009) The farther, the safer. A manifesto for securely navigating synthetic species away from the old living world. Syst Synth Biol 3:77-84

83. Martin J, Harré R (1982) Metaphor in science. In: Miall DS (ed) Metaphor. Problems and perspectives. Harvester Press, Sussex, pp 89-105

84. Matern H, Ried J, Braun M, Dabrock P (2016) Living machines. On the genesis and systematic implications of a leading metaphor of synthetic biology. In: Boldt J (ed) Synthetic biology. Metaphors, worldviews, ethics and law. Springer VS, Wiesbaden, pp 47-60

85. Max-Planck-Gesellschaft (2015). The toolbox of life. April 21, 2015. https://www.mpg.de/9187240/syntheticbiology-toolbox-of-life. Accessed 1 Sept 2019

86. McLeod C, Nerlich B (2017) Synthetic biology, metaphors and responsibility. Life Sci Soc Pol 13:1-13. https://doi. org/10.1186/s40504-017-0061-y

87. Mittelstraß J (2018) Transdisziplinarität. In Mittelstraß J. (Ed.) Enzyklopädie Philosophie und Wissenschaftstheorie (Vol. 8: Th-Z), 2nd ed. (revised). Metzler, Stuttgart, pp. 104-105)

88. Moore GE (1903) Principia Ethica. http://fair-use.org/g-emoore/principia-ethica. Accessed 1 Sept 2019

89. Morange M (2010) The resurrection of life. Orig Life Evol Biosph 40:179-182

90. Müller M (2016a) 'First species whose parent is a computer' - synthetic biology as technoscience, colonizing futures, and the problem of the digital. In: Hagen K, Engelhard M, Toepfer G (eds) Ambivalences of creating life. Societal and philosophical dimensions of synthetic biology. Springer, Switzerland, pp 101-113

91. Müller O (2016b) Synthetic biology. On epistemological Black boxes, human self-assurance, and the hybridity of practices and values. In: Boldt J (ed) Synthetic biology. Metaphors, worldviews, ethics and law. Springer VS, Wiesbaden, pp 31-46

92. Nordmann A (2014) Synthetic biology at the limits of science. In: Giese B, Pade C, Wigger H, von Gleich A (eds) Synthetic biology. Character and impact. Springer, Switzerland, pp 31-58

93. Pedrolli DB, Ribeiro NV, Squizato PN, de Jesus VN, Cozetto DA (2019) Engineering microbial living therapeutics: the synthetic biology toolbox. Trends Biotechnol 37(1):100-115

94. Poser H (2016) Homo creator. Technik als philosophische Herausforderung. Springer VS, Wiesbaden

95. Ricken F (2005) bios / Leben, Lebensweise. In: Höffe O (ed) Aristoteles-Lexikon. Kröner, Stuttgart, pp 98-99

96. Ried J, Braun M, Dabrock P (2011) Unbehagen und kulturelles Gedächtnis. Beobachtungen zur gesellschaftlichen Deutungsunsicherheit gegenüber Synthetischer Biologie. In: Dabrock P, Bölker M, Braun M, Ried J (eds) Was ist Leben im Zeitalter seiner technischen Machbarkeit? Beiträge zur Ethik der Synthetischen Biologie. Verlag Karl Alber, Freiburg, pp 345-369

97. Ruiz-Mirazo K, Moreno A (2013) Synthetic biology. Challenging life in order to grasp, use and extend it. Biol Theory 8:376-382
98. Sauter A (2011) Synthetische Biologie. Finale Technisierung des Lebens - oder Etikettenschwindel? TAB-Brief 39:23-30

99. Schmidt M (2009) Do I understand what I can create? Biosafety issues in synthetic biology. In: Schmidt M, Kelle A, Ganguli A, Vriend H (eds) Synthetic biology. The technoscience and its societal consequences. Springer, Dordrecht, pp 81-100

100. Schmidt M (2010) Xenobiology. A new form of life as the ultimate biosafety tool. Bioessays 32(4):322-331

101. Schmidt K (2016) Vom genetischen Programm zum Entwicklungssystem. Warum das Genom kein Kuchenrezept ist. In: Heinemann G, Timme R (eds) Aristoteles und die heutige Biologie. Vergleichende Studien. Verlag Karl Alber, Freiburg, pp 53-79

102. Schmidt M, de Lorenzo V (2012) Synthetic constructs in/for the environment. Managing the interplay between natural and engineered biology. FEBS Lett 586(15):2199-2206

103. Schrödinger E (1944) What is life? The physical aspect of the living cell. Based on lectures delivered under the auspices of the Dublin Institute for Advanced Studies at trinity college, Dublin, in February 1943. Cambridge University Press

104. Schummer J (2011) Das Gotteshandwerk. Die künstliche Herstellung von Leben im Labor, Suhrkamp, Frankfurt am Main

105. Schwille P (2011) Bottom-up synthetic biology. Engineering in a Tinkerer's world. Science 333:1252-1254

106. Seitz SB, Hagen K (2016) Inter- and transdisciplinary interfaces in synthetic biology. NanoEthics 10(3):265-268

107. Steizinger J (2016) Engineers of life? A critical examination of the concept of life in the debate on synthetic biology. In: Hagen K, Engelhard M, Toepfer G (eds) Ambivalences of creating life. Societal and philosophical dimensions of synthetic biology. Springer, Switzerland, pp 275-292

108. Szymanski EA (2018) Who are the users of synthetic DNA? Using metaphors to activate microorganisms at the Center of Synthetic Biology. Life Sci Soc Pol 14:1-16. https://doi.org/10.1186/s40504-018-0080-3

109. Toellner R (1980) Leben. VI. Der biologische Lebensbegriff. In: Ritter J, Gründer K (eds) Historisches Wörterbuch der Philosophie (Vol. 5: L-Mn), Schwabe, Basel, pp 97-103

110. Toepfer G (2011) Leben. In: Historisches Wörterbuch der Biologie. Geschichte und Theorie der biologischen Grundbegriffe, 2nd edn. Metzler, Stuttgart, pp 420-483

111. Toepfer G (2016) The concept of life in synthetic biology. In: Engelhard M (ed) Synthetic biology analysed. Tools for discussion and evaluation. Springer, Switzerland, pp 71-88

112. Turbayne CM (1970) The myth of metaphor. University of South Carolina Press

113. Venter JC (2012) What is life? http://edge. org/conversation/what-is-life. Accessed 1 Sept 2019

114. Weinrich H (1963) Semantik der kühnen Metapher. Dtsch Vierteljahrsschr Literaturwiss Geistesgesch 37(3): 325347. https://doi.org/10.1007/BF03375260

115. Weiss MG (2011) Verstehen, was wir herstellen können? Martin Heidegger und die Synthetische Biologie. In: Dabrock P, Bölker M, Braun M, Ried J (eds) Was ist 
Leben - im Zeitalter seiner technischen Machbarkeit. Verlag Karl Alber, Freiburg, pp 173-193

116. Witt E (2012) Konzepte und Konstruktionen des Lebenden. Philosophische und biologische Aspekte einer künstlichen Herstellung von Mikroorganismen. Verlag Karl Alber, Freiburg

117. Wolters G, Mittelstraß J (2010) Leben. In: Mittelstraß J (ed) Enzyklopädie Philosophie und Wissenschaftstheorie (Vol. 4: Ins - Loc), 2nd edition (revised). Metzler, Stuttgart, pp 474-477
118. Zwart H (2018) Scientific iconoclasm and active imagination. Synthetic cells as technoscientific mandalas. Life Sci Soc Pol 14. https://doi.org/10.1186/s40504-018-0075-0

Publisher's Note Springer Nature remains neutral with regard to jurisdictional claims in published maps and institutional affiliations. 